\title{
Assessment of the structure and variability of Weddell Sea water masses in distinct ocean reanalysis products
}

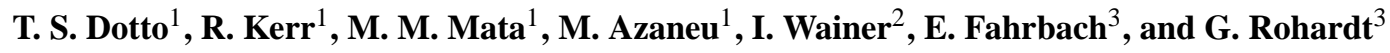 \\ ${ }^{1}$ Laboratório de Estudos dos Oceanos e Clima, Instituto de Oceanografia, Universidade Federal do Rio Grande - FURG, \\ Rio Grande, RS, 96203-900, Brazil \\ ${ }^{2}$ Laboratório de Oceanografia Física, Clima e Criosfera, Instituto Oceanográfico, Universidade de São Paulo - USP, \\ São Paulo, SP, 05508-120, Brazil \\ ${ }^{3}$ Stiftung Alfred-Wegener-Institut für Polar- und Meeresforschung in der Helmholtz-Gemeinschaft, \\ Fachbereich Klimawissenschaften, Sektion Messende Ozeanographie, Postfach 120121 Bremerhaven, Germany \\ Correspondence to: T. S. Dotto (tiagodotto@ furg.br)
}

Received: 16 January 2014 - Published in Ocean Sci. Discuss.: 14 February 2014

Revised: 5 May 2014 - Accepted: 10 May 2014 - Published: 23 June 2014

\begin{abstract}
We assessed and evaluated the performance of five ocean reanalysis products in reproducing essential hydrographic properties and their associated temporal variability for the Weddell Sea, Antarctica. The products used in this assessment were ECMWF ORAS4 (European Centre for Medium-Range Weather Forecasts Ocean Reanalysis System 4), CFSR (Climate Forecast System Reanalysis), MyOcean UR025.4 (University of Reading), ECCO2 (Estimating the Circulation and Climate of the Ocean, Phase II) and SODA (Simple Ocean Data Assimilation). The present study focuses on the Weddell Sea deep layer, which is composed of the following three main water masses: Warm Deep Water (WDW), Weddell Sea Deep Water (WSDW) and Weddell Sea Bottom Water (WSBW). The MyOcean UR025.4 product provided the most accurate representation of the structure and thermohaline properties of the Weddell Sea water masses when compared with observations. All the ocean reanalysis products analyzed exhibited limited capabilities in representing the surface water masses in the Weddell Sea. The CFSR and ECCO2 products were not able to represent deep water masses with a neutral density $\geq 28.40 \mathrm{~kg} \mathrm{~m}^{-3}$, which was considered the WSBW's upper limit throughout the simulation period. The expected WDW warming was only reproduced by the SODA product, whereas the ECCO2 product was able to represent the trends in the WSDW's hydrographic properties. All the assessed ocean reanalyses were able to represent the decrease in the WSBW's density, except the SODA product in the inner Weddell Sea. Improvements in
\end{abstract}

parameterization may have as much impact on the reanalyses assessed as improvements in horizontal resolution primarily because the Southern Ocean lacks in situ data, and the data that are currently available are summer-biased. The choice of the reanalysis product should be made carefully, taking into account the performance, the parameters of interest, and the type of physical processes to be evaluated.

\section{Introduction}

The Southern Ocean is considered an important region for better understanding the global overturning circulation (GOC) because of the regional formation and export of bottom waters to the global ocean (e.g., Talley, 2013). The GOC's deeper branch starts with the formation of Antarctic Bottom Water (AABW), which occurs regionally around the Antarctic margins (Whitworth et al., 1998) as a result of the mixing of warm and salty intermediate waters with near-surface freezing-point shelf or ice-shelf waters. The AABW's properties are dependent on several complex physical processes coupled with atmosphere-ocean-cryosphere processes, including sea-ice formation, opening of coastal polynyas, melting under deep ice shelves, deep ocean convection, and entrainment of overlying or surrounding waters (e.g., Carmack and Foster, 1975; Foldvik et al., 1985; Nicholls et al., 2009; Ohshima et al., 2013). 
The Weddell Sea is thought to be the major contributor to AABW's formation and export to the global ocean (e.g., Orsi et al., 1999; Huhn et al., 2008; Kerr et al., 2012a; van Sebille et al., 2013). Regionally, the bottom layer consists of Weddell Sea Bottom Water (WSBW), the densest AABW variety in the Weddell Sea. WSBW is produced by a mixture of Shelf Waters (SW) with Warm Deep Water (WDW) or modified WDW (MWDW) near the shelf-slope break (e.g., Foster and Carmack, 1976; Foldvik et al., 1985). This bottom water mass is primarily confined to the Weddell Basin (Orsi et al., 1993) and eventually can be exported from the source region due to mixture with overlying Weddell Sea Deep Water (WSDW) or flow through deep channels (Orsi et al., 1995). WSDW is the less dense Weddell Sea deep water variety that contributes to the AABW after leaving the source areas. It can be formed either directly or by a mixture of WSBW with WDW during the downslope flow (Orsi et al., 1993, 1999). Because WSDW is less dense than WSBW, it is easily exported from the Weddell Sea into the global ocean through the narrow passages of the South Scotia Ridge (e.g., Naveira Garabato et al., 2002; Franco et al., 2007). WDW is a branch of the Circumpolar Deep Water (CDW) that enters the Weddell Sea at ca. $30^{\circ} \mathrm{E}$ (Gouretski and Danilov, 1993). Thus, any change occurring during the $\mathrm{AABW}$-formation process can be reflected in global circulation via the deep branch of the overturning cell (Lumpkin and Speer, 2007; Talley, 2013).

Over the past few decades, changes in the thermohaline properties of AABW source waters have been reported, such as freshening of the dense waters in the shelf regions (e.g., Hellmer et al., 2011; Azaneu et al., 2013) and long-term warming of WDW within the Weddell Sea (e.g., Robertson et al., 2002; Smedsrud, 2005). In turn, WSBW in the inner Weddell Sea also experienced warming during the second half of the 1990s (Fahrbach et al., 2004, 2011). Moreover, Huhn et al. (2013) found that all deep water masses in the Weddell Sea were continually growing older and becoming less ventilated from 1984 to 2011 . In concordance with these findings, a decrease in the WSBW's contribution $(\sim 20 \%)$ to the total water mass mixture in the Weddell Basin occurred in the 1980s and 1990s near the Greenwich Meridian and at the tip of the Antarctic Peninsula (Kerr et al., 2009a). More recently, Azaneu et al. (2013) fully investigated the most complete Southern Ocean data set available and found a reduction in the volume of AABW in addition to warming and decreasing density from 1958 to 2011 in the deep and bottom layers south of $60^{\circ} \mathrm{S}$. Despite the reported freshening of the AABW layer at the Drake Passage during the period 19932010 (Jullion et al., 2013), no sign of this freshening trend was found by Azaneu et al. (2013) in WSDW/WSBW layers in the last 50 years (1958-2011) in the inner Weddell Sea. In a global context, the AABW's layer in the global basins underwent a contraction from the 1980s to the 2000s (Purkey and Johnson, 2012).
In spite of the efforts made to understand the physical processes associated with those long-term changes, the regional seas of the Southern Ocean have limited and generally summer-biased sampling opportunities. The lack of consistent in situ observations precludes a better understanding of connections between those processes and their possible implications for the global climate. To overcome this limitation in data coverage, numerical ocean models powered by data-assimilation systems (i.e., reanalysis systems) are potentially valuable tools. Reanalysis provides a physical picture of the global climate over a period during which observational data are available, making it possible to minimize the information gaps in spatial and temporal coverage in those regions. However, ocean reanalysis systems can produce spurious trends and inhomogeneity (Carton and Santorelli, 2008) caused by the limited and summer-biased sampling, especially at high southern latitudes (Bromwich et al., 2011). Moreover, a good representation of the physical processes occurring in ocean and climate models together with accurate hydrographic data observed in the Weddell Sea, which can be investigated through ocean reanalysis products, should significantly influence the hydrography of the Southern Ocean and South Atlantic (Hellmer et al., 2005). In this way, validation of ocean reanalysis products is needed to evaluate the suitability, consistency, and applicability of these products for long-term investigations in the Southern Ocean.

The present study aims to assess and compare the representation and variability of the hydrographic properties of Weddell Sea deep water masses using five recent ocean reanalysis products to identify which reanalysis product best reproduces the main regional oceanographic features. The paper is organized as follows: Sect. 2 provides a description of the five ocean reanalysis products investigated here. The observational data set used for the structure and variability assessments of the Weddell Sea water masses is described in Sect. 3. A comparison of the results of each ocean reanalysis product is described in Sect. 4. Finally, Sect. 5 summarizes and addresses the study's main results and conclusions.

\section{Ocean reanalysis data sets}

We assessed the capabilities of the five ocean reanalysis products, which are briefly described below, in terms of the potential temperature $(\theta)$, salinity $(S)$ and neutral density $\left(\gamma^{\mathrm{n}}\right.$; Jackett and McDougall, 1997) of seawater. The main characteristics of the ocean reanalysis products are reported in Table 1. To assess the robustness of those products for modeling the Weddell Sea, we compared the ocean reanalysis data sets against an observational data set for the period spanning from the 1980s to the 2000s.

The European Centre for Medium-Range Weather Forecasts Ocean Reanalysis System 4 (ECMWF ORAS4) is a global reanalysis system based on the ocean model Nucleus 


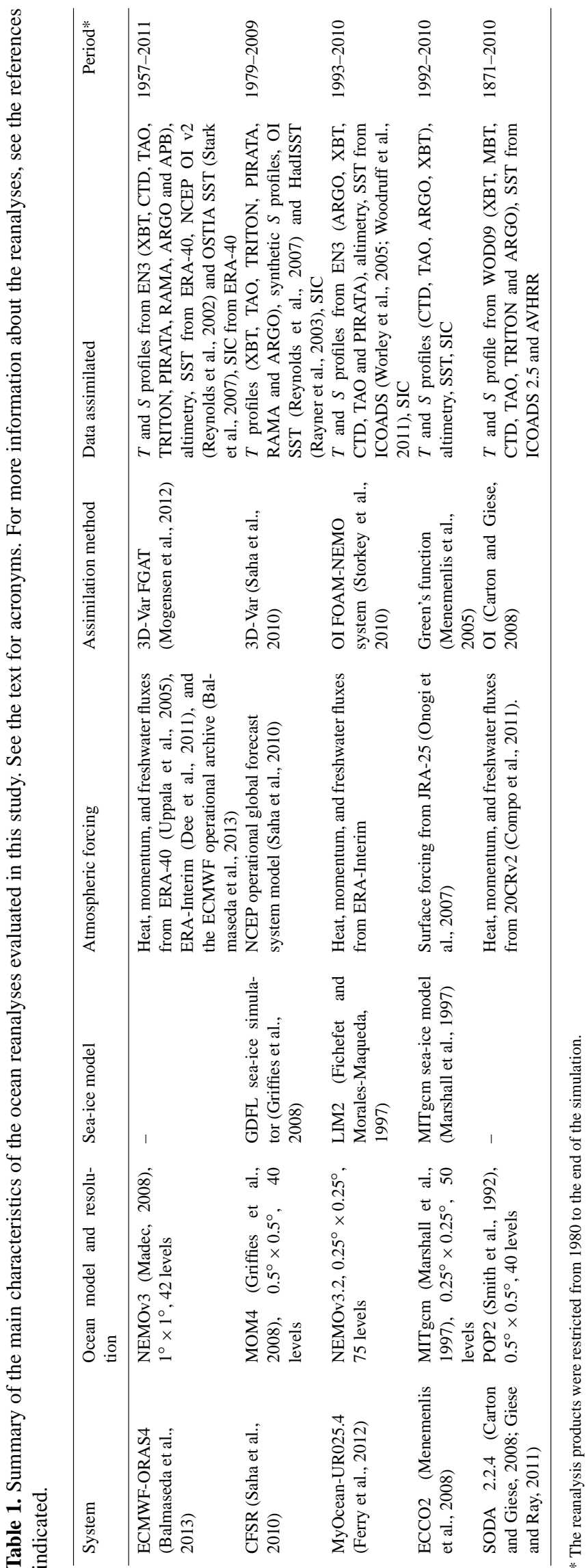

for European Modelling of the Ocean (NEMO) version 3 (Madec, 2008). The method of data assimilation used is 3DVar (three-dimensional variation; Mogensen et al., 2012). ECMWF ORAS4 assimilates the temperature and salinity profiles from EN3, sea-level anomalies and sea surface temperature (SST). The sea-ice concentration (SIC) data are from ERA-40 (ECMWF 40 Years Reanalysis), and they are only used to correct the SST values (Balmaseda et al., 2013). The ocean model is driven by daily fluxes of heat, momentum and freshwater from the ERA-40 (prior to 1989), the ERA-Interim (from 1989 to 2010) and ECMWF's operational archive (after 2010; Balmaseda et al., 2013). This ocean reanalysis product is hereafter referred to as ECMWF.

The Climate Forecast System Reanalysis (CFSR) is a coupled atmosphere-ocean-land surface-sea-ice data assimilation. The ocean system is based on the Modular Ocean Model version 4p0d (MOM4), which is coupled with an interactive ice model (Griffies et al., 2008). CFSR uses 3D-Var as the data assimilation method (Saha et al., 2010). The reanalysis system assimilates temperature profiles from XBT (expendable bathythermograph), moorings, Argo floats and SST only in the top $750 \mathrm{~m}$ (Xue et al., 2011). CFSR also assimilates synthetic salinity profiles (Xue et al., 2011) and SIC (Saha et al., 2010). The atmospheric model is based on the previous National Center for Environmental Prediction (NCEP) operational global forecast system (Saha et al., 2010). It is important to note that the CFSR ocean reanalysis uses a combination of six data streams, each from a different initial condition (Saha et al., 2010). This segmentation leads to serious discontinuity in the deep ocean, which has consequences for decadal prediction (Xue et al., 2011). For this reason, CFSR assessment was only performed for climatological analysis and was not included in the evaluation of time series properties.

The MyOcean University of Reading (UR025.4) reanalysis product is performed with the ocean model NEMO version 3.2 coupled with Louvain-la-Neuve ice model version 2 (LIM2; Fichefet and Morales-Maqueda, 1997). It includes an annual estimation of Antarctica ice sheet melt in the oceanic model (Ferry et al., 2012). The assimilation system used in UR025.4 is an Optimal Interpolation (OI) scheme based on the UK Met Office operational FOAM-NEMO system (Storkey et al., 2010). It assimilates in situ and satellite SST data, satellite sea level data, satellite SIC data, and in situ temperature and salinity profile data from the EN3 data set. Surface atmospheric forcing is obtained from the ERAInterim, and bulk fluxes are calculated as suggested by Large and Yeager (2009). Hereafter, the UR025.4 reanalysis product is referred to as MyOcean.

The Estimating the Circulation and Climate of the Ocean, Phase II (ECCO2) reanalysis system is based on the global ocean model of the Massachusetts Institute of Technology general circulation model (MITgcm; Marshall et al., 1997) in a cube-sphere grid. MITgcm is coupled to a sea-ice model that computes ice thickness, ice concentration, and snow 
cover. ECCO2 uses Green's function as an assimilation system (Menemenlis et al., 2005). It assimilates sea surface height anomalies, SST, temperature and salinity profiles, and sea-ice concentration, motion and thickness. We used the solution "cube 92 " with a $0.25^{\circ}$ regular latitude-longitude grid here (hereafter referred to as ECCO2). The surface forcing of this solution is provided by the Japanese 25 -year Reanalysis (JRA-25; Onogi et al., 2007). We restricted the analysis to the period 1992-2005 because ECCO2 has poorly represented the water properties in most of the Southern Ocean during the last 6 years (2005-2010) of the simulation (Azaneu et al., 2014), showing abrupt changes in the properties of deepwater masses. These authors showed that after the opening of the oceanic polynya in 2004 , the thermohaline values of Weddell Sea water masses became unrealistic, most likely because of strong, open-ocean deep convection simulated in the Weddell Sea.

Simple Ocean Data Assimilation version 2.2.4 (hereafter SODA) is a global reanalysis system based on the Parallel Ocean Program version 2.0.1 (Smith et al., 1992). The assimilation system used in SODA is an OI multivariate sequentialtype scheme (Carton and Giese, 2008). It assimilates in situ temperature and salinity profiles and in situ and satellite SSTs. The ocean model is forced by fluxes of heat, momentum and freshwater from the Twentieth Century Reanalysis Project version 2 (20CRv2; Compo et al., 2011). SODA does not use a sea-ice model, although the surface heat flux is modified when the surface temperature reaches the freezing point of seawater.

\section{Observational data sets, reanalysis outputs and methods used for reanalysis evaluation}

The in situ $\theta$ and $S$ were selected from two WOCE (World Ocean Circulation Experiment) hydrographic repeat sections in the Weddell Sea (Table 2; Fig. 1) as follows: (i) section WOCE A12 (also referred to as WOCE SR2 in the literature) along the Greenwich Meridian, with a sampling period spanning from 1984 to 2010 (e.g., Fahrbach et al., 2011); and (ii) section WOCE SR4 between Joinville Island and Kapp Norvegia, with a sampling period spanning between 1989 and 2010 (e.g., Fahrbach et al., 2004). Section WOCE A12 was restricted to latitudes higher than $60^{\circ} \mathrm{S}$. All observed $\theta$ and $S$ data were collected by high-accuracy CTDs. Those sections were chosen to be evaluated in the Weddell Sea because of the availability of historical data nearby, because of their importance in regional circulation and the export of deep waters (e.g., Naveira Garabato et al., 2002; Klatt et al., 2005; Kerr et al., 2012a), and because they are representative of the entire Weddell Basin. Reanalysis grid points closer to the geographical location of the in situ hydrographic stations (observations) were selected from the monthly mean fields corresponding in time to the period of the in situ measurements.
Table 2. Overview of the observed hydrographic sections used for the validation of the reanalyses. Details of the observed data can be found in Whitworth and Nowlin (1987), Fahrbach et al. (2001, 2004, 2007, 2011), Fahrbach and De Baar (2010) and Rohardt et al. (2011).

\begin{tabular}{lll}
\hline Expedition & Cruise period (dd/mm/yyyy) & WOCE section \\
\hline AJAX (leg 2) & $16 / 01 / 1984-29 / 01 / 1984$ & A12 \\
ANT-VIII/2 & $06 / 09 / 1989-31 / 10 / 1989$ & SR4 \\
ANT-IX/2 & $16 / 11 / 1990-30 / 12 / 1990$ & SR4 \\
ANT-X/4 & $21 / 05 / 1992-30 / 07 / 1992$ & A12 \\
ANT-X7 & $03 / 12 / 1992-23 / 01 / 1993$ & SR4 \\
ANT-XIII/4 & $17 / 03 / 1996-20 / 05 / 1996$ & A12/SR4 \\
ANT-XV/4 & $28 / 03 / 1998-23 / 05 / 1998$ & A12/SR4 \\
ANT-XVI/2 & $09 / 01 / 1999-16 / 03 / 1999$ & A12 \\
ANT-XVIII/3 & $05 / 12 / 2000-12 / 01 / 2001$ & A12 \\
ANT-XX/2 & $24 / 11 / 2002-23 / 01 / 2003$ & A12 \\
ANT-XXII/3 & $21 / 01 / 2005-06 / 04 / 2005$ & A12/SR4 \\
ANT-XXIV/3 & $06 / 02 / 2008-16 / 04 / 2008$ & A12/SR4 \\
ANT-XXVII/2 & $28 / 11 / 2010-05 / 02 / 2011$ & A12/SR4
\end{tabular}

${ }^{a}$ Does not extend all of the way to the shelf in the eastern Weddell Sea. ${ }^{\mathrm{b}}$ Only 2010 data are used.

Because the ocean reanalysis data sets have different vertical resolutions and because the position of observed stations varies between occupations, we linearly interpolated the observational data sets to the vertical grid for each reanalysis to allow direct comparisons among the ocean reanalysis products and observations. Horizontally, the reanalysis and the observational data sets were spatially interpolated and gridded with $0.5^{\circ}$ latitude and $1^{\circ}$ longitude for the WOCE A12 and WOCE SR4 sections, respectively.

The structure of the water column was evaluated using classical $\theta-S$ diagram comparisons, and simple differences in the hydrographic properties of the sections between the reanalysis results and field observations were calculated. We used the root-mean-square error (RMSE) criteria following Heuzé et al. (2013) to evaluate which ocean reanalysis product better represented the entire water column. In addition, the statistical patterns of the hydrographic fields were evaluated using a normalized Taylor diagram (Taylor, 2001) for a more robust comparison of the reanalysis products being evaluated. Briefly, the normalized Taylor diagram combines statistical parameters (correlation coefficient $-r$, normalized standard deviation $-\sigma_{\mathrm{n}}$, and normalized centered root-meansquare error - CRMSE) to compare the spatial patterns from the ocean reanalyses and the observed hydrographic fields. The CRMSE is used as a measure of the difference between values predicted by a model and values that are observed, minimizing the effect of the model mean bias. Further details and equations are presented in Taylor (2001). We performed the statistical analysis considering the entire water column and used the field observations as the reference data set. The reanalysis fields that showed better concordance with the observations lie closer to the reference point in the Taylor 


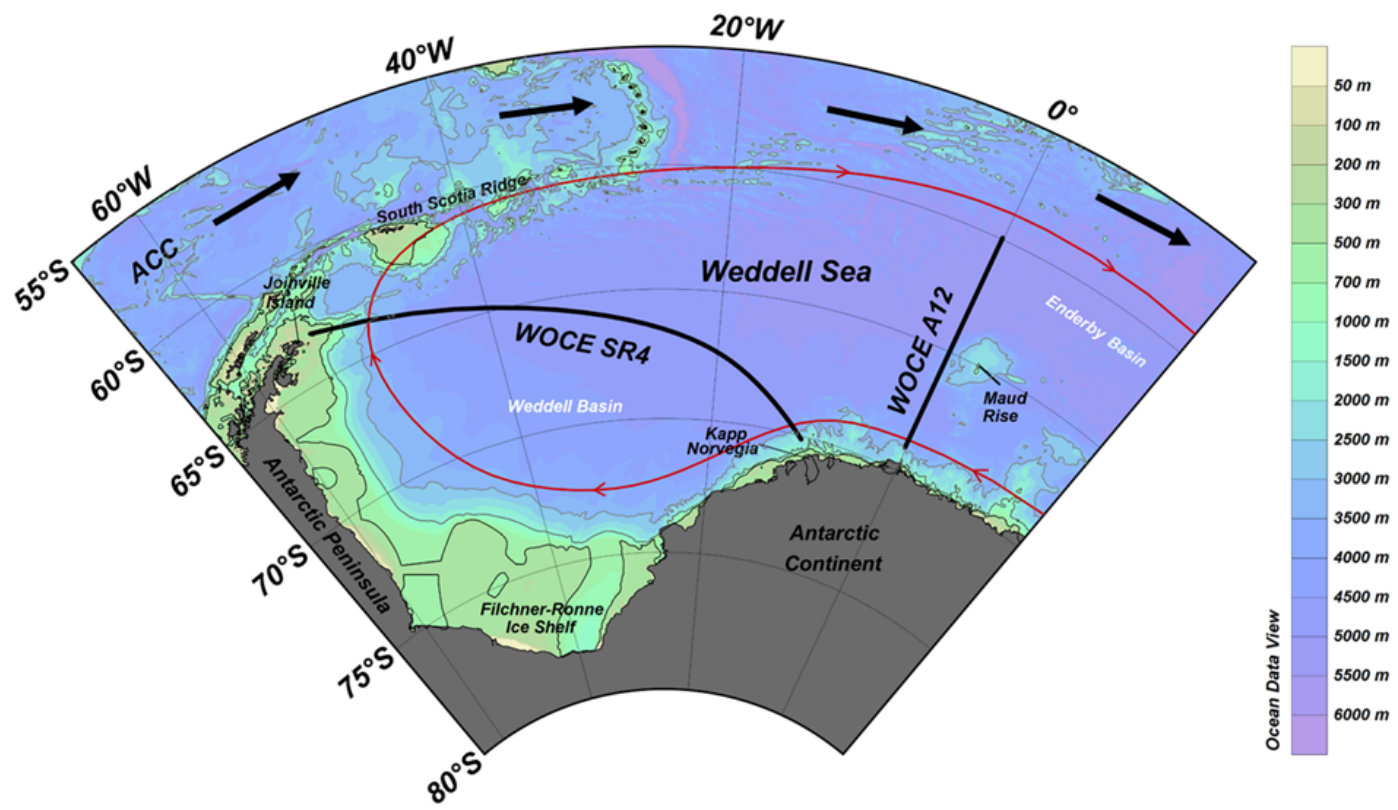

Figure 1. Schematic locations of the hydrographic sections. WOCE A12 is found along the Greenwich Meridian, and WOCE SR4 lies between Joinville Island and Kapp Norvegia. The arrows indicate the direction of the Antarctic Circumpolar Current (ACC; black) and the Weddell Gyre (red) flows. The thin black and gray lines represent the 500, 1500, and $3000 \mathrm{~m}$ isobaths.

diagram (i.e., had low CRMSE and high $r$ and $\sigma_{\mathrm{n}}$ values close to 1 ).

For the time series of water mass properties, we show the range of values for the station data sets, excluding the station set of 1998 at WOCE SR4. We used the original resolution of each data set (i.e., a monthly time series) to evaluate patterns of variability in the hydrographic properties, and the annual linear trend was fit for each time series of hydrographic properties.

\subsection{Definition of the water masses}

The Weddell Sea water masses were defined based on the $\gamma^{\mathrm{n}}$ isopycnal surfaces for all data sets. The interface between the surface and intermediate layers was defined as proposed by Franco et al. (2007). We used the definition of Orsi et al. (1999) to distinguish between the deep and bottom layers in the inner Weddell Sea. Thus, we separated the water mass layers from the surface to the bottom using the $\gamma^{\mathrm{n}}$ isopycnals of $28.1,28.27$, and $28.4 \mathrm{~kg} \mathrm{~m}^{-3}$, corresponding to the AASW-WDW, WDW-WSDW, and WSDW-WSBW interfaces, respectively.

\section{Results}

\subsection{Water column structure and simple differences in hydrographic properties}

In general, all of the ocean reanalysis products that were evaluated captured the main structure of the water masses in the Weddell Sea (Figs. 2, 3). The lighter AASW could be observed lying above the warm and salty intermediate water (WDW), with $\theta$ and $S$ decreasing with depth and marking the dense deep (WSDW) and bottom (WSBW) waters of the Weddell Sea. The ECMWF, MyOcean and SODA products had the $\theta-S$ structures that most closely approximated the observations of both the WOCE A12 and WOCE SR4 sections, especially when considering the intermediate and deep layers (WDW, WSDW, and WSBW). ECCO2 showed a similar $\theta-S$ structure when compared with observation data. However, its dense WSBW layer was $\sim 0.2^{\circ} \mathrm{C}$ warmer than the in situ data. The CFSR product captured the stratification of the water masses along the water column, but its $\theta-S$ structure was displaced by warmer (except for the WDW layer) and fresher hydrographic properties, consequently making most layers lighter than the in situ data.

All the ocean reanalysis products evaluated had difficulty representing the AASW hydrographic values (Figs. 2-9). The mismatch between the data and the surface water representations was most likely a consequence of difficulties the products faced in reproducing several complex processes and fluxes acting on the ocean surface, which are seasonally influenced by physical processes at the air-sea and sea iceocean interfaces (Whitworth et al., 1998). The majority of the reanalyses showed the mean differences colder by $0.002-$ $0.16^{\circ} \mathrm{C}$ than those actually observed in the data recorded in situ along the WOCE A12 line (Fig. 4). Conversely, for the WOCE SR4 section, all the reanalyses revealed mean differences that were $0.06-0.4{ }^{\circ} \mathrm{C}$ warmer than the observations (Fig. 5). For $S$, most of the reanalyses overestimated this field 

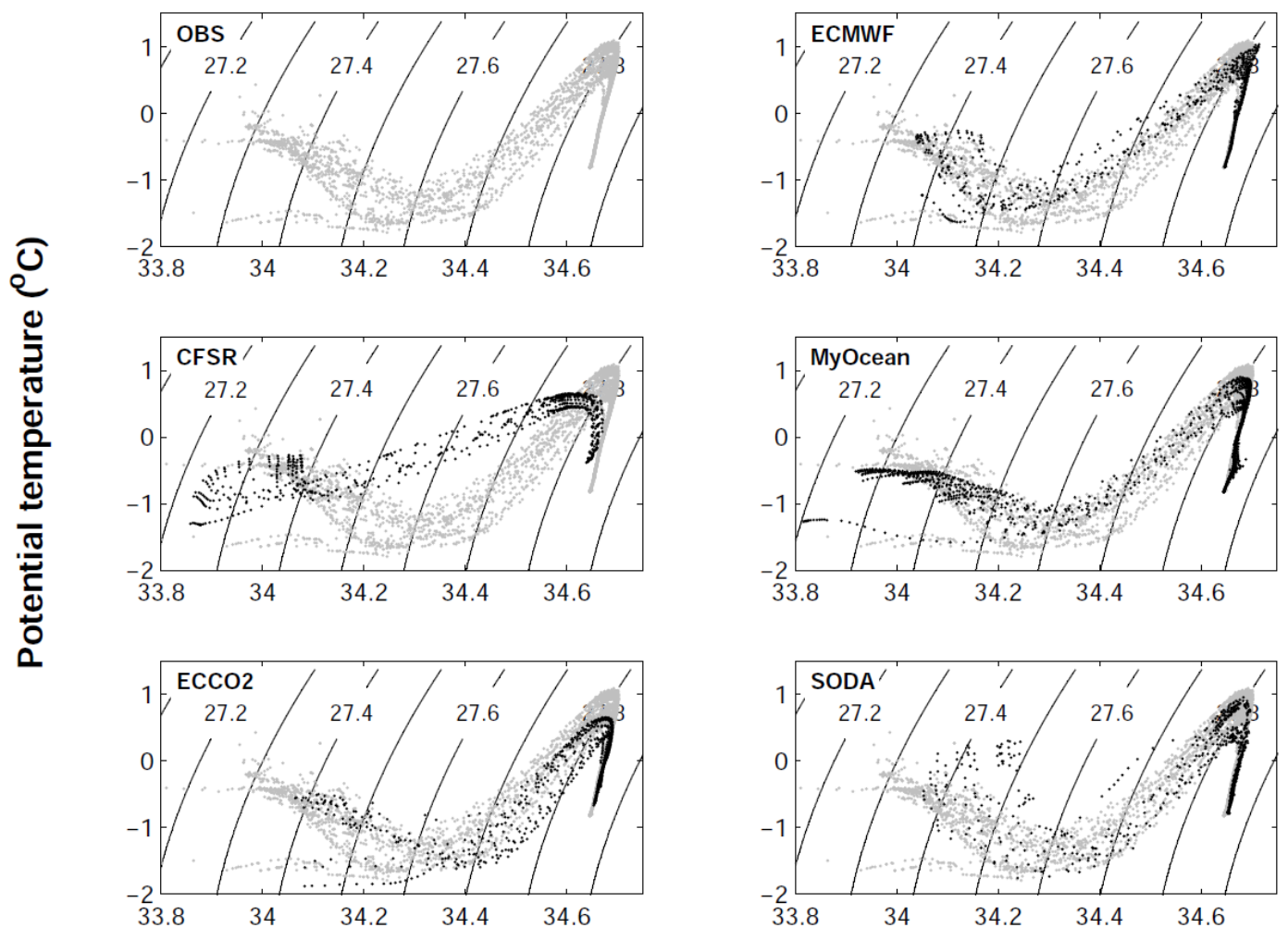

\section{Salinity}

Figure 2. $\theta-S$ diagrams from section WOCE A12. Gray (black) dots are observation (reanalysis) data. Solid lines are potential density isopycnals.

by a mean difference of $0.01-0.11$ in both sections (Figs. 6, 7 ), whereas for the $\gamma^{\mathrm{n}}$ field, the majority of the reanalyses showed a mean underestimation of $0.004-0.3 \mathrm{~kg} \mathrm{~m}^{-3}$

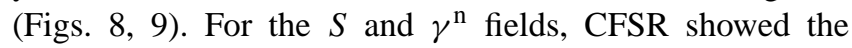
greater mean differences $(-0.3 \pm 0.17$ for salinity and $-0.3 \pm$ $0.16 \mathrm{~kg} \mathrm{~m}^{-3}$ for neutral density), whereas MyOcean detected minor differences (an overestimation of $0.003 \pm 0.09$ for $S$ and an underestimation of $0.004 \pm 0.08 \mathrm{~kg} \mathrm{~m}^{-3}$ for $\gamma^{\mathrm{n}}$ ). The greatest mean differences were found primarily at the AASW-WDW interface and near the continental boundaries (Figs. 4-9). Note that along the WOCE sections, depending on the product, the simulated values both underestimated and overestimated the observations (Figs. 4-9).

In general, the majority of the ocean reanalysis products showed cold and fresh waters relative to the observations at intermediate depths (Figs. 4-7). However, the ECMWF, CFSR and ECCO2 products did not appear to follow this general pattern for $\theta$ below a depth of $\sim 1000 \mathrm{~m}$. The $\theta$ difference varied from $\sim 0.05^{\circ} \mathrm{C}$ for the MyOcean product to more than $\sim 0.2^{\circ} \mathrm{C}$ for the CFSR and ECCO 2 products (Figs. 4, $5)$. The differences in the $S$ field were greater than 0.05 for CFSR and ECMWF (near the Antarctic Margin) in both the WOCE A12 (Fig. 6) and WOCE SR4 (Fig. 7) sections. The MyOcean reanalysis had the smallest differences in the $S$ field compared to the observed data $(<0.003)$ at the intermediate layer among all of the reanalysis products evaluated here. In this layer, the $\gamma^{\mathrm{n}}$ field was clearly dependent on the $S$ differences found in each ocean reanalysis product. The differences in the reanalyses' intermediate layers were most likely advected with WDW into the Weddell Gyre because the colder and fresher WDW variety could be observed in section WOCE A12 (Figs. 4, 6).

At the deep layer, the reanalysis showed two distinct patterns of $\theta$ differences. The MyOcean and SODA reanalysis products were generally colder than observations by less than $0.05^{\circ} \mathrm{C}$, whereas CFSR and ECCO2 were warmer for both the WOCE A12 (Fig. 4) and WOCE SR4 sections (Fig. 5). These latter reanalysis products overestimated $\theta$ values $\left(\sim 0.2-0.4{ }^{\circ} \mathrm{C}\right.$ warmer), leading to the representation of bottom waters that did not reach the WSBW temperature threshold (i.e., $-0.7^{\circ} \mathrm{C}$; Carmack and Foster, 1975) or its corresponding neutral density $\left(28.4 \mathrm{~kg} \mathrm{~m}^{-3}\right)$. In contrast, the ECMWF product was warmer than observations at section WOCE A12 (Fig. 4) and colder at WOCE SR4 (Fig. 5). This reanalysis also showed a temperature overestimation of $\sim 0.3^{\circ} \mathrm{C}$ near the Antarctic margins at $1000-2000 \mathrm{~m}$ depth (Figs. 4, 5) due to a representation of the WDW inflow core deeper and closer to the Antarctic continent than indicated 

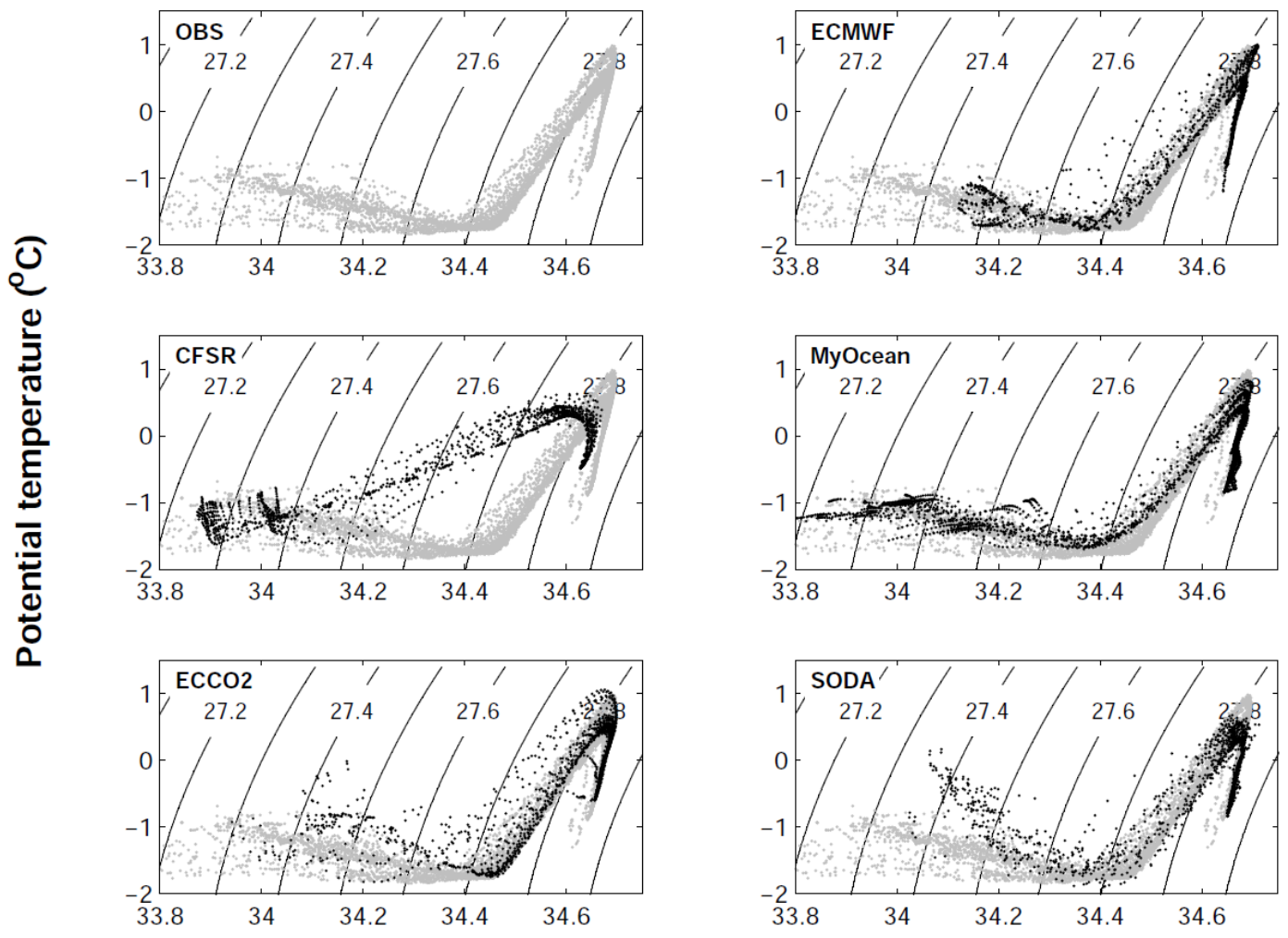

\section{Salinity}

Figure 3. Same as in Fig. 2, but for section WOCE SR4.

by the observations. At this layer, the $S$ field showed smaller differences than those of the whole upper structure of the water column, as demonstrated by the underestimation of $S$ in almost all the sections by all the products, except for the WOCE SR4 section by the CFSR product (Figs. 6, 7). The $\theta$ value had greater influence on the $\gamma^{\mathrm{n}}$ field at this layer because of the smaller differences in $S$. The salinity differences in the CFSR results $(0.025-0.05$; Figs. 6, 7), associated with its warm ocean representation $\left(>0.2^{\circ} \mathrm{C}\right.$; Figs. 4,5$)$, helped to increase the difference in density with respect to observations, resulting in differences of $\sim-0.1 \mathrm{~kg} \mathrm{~m}^{-3}$ (Figs. 8, 9). None of the reanalysis systems evaluated represented the downslope flow of the WSBW plume in the western continental slope of the WOCE SR4 section during the period analyzed (Fig. 9) as expected from observations (e.g., Fig. 02 of Fahrbach et al., 2001).

\subsection{Statistical representation of the hydrographic spatial fields}

We used the RMSE to quantify the accuracy of the ocean reanalysis products in representing the hydrographic fields. A reanalysis was considered accurate if, for each hydrographic parameter, the RMSE was smaller than the mean RMSE of the five reanalysis products. Table 3 summarizes the accuracy threshold for each parameter. The use of RMSE criteria revealed that ECMWF and MyOcean could be considered accurate in their representation of almost all parameters except for WOCE SR4 $\theta$ and WOCE A12 $S$, respectively (Table 3). For SODA, only $S$ and $\gamma^{\mathrm{n}}$ were accurate in both sections. $\mathrm{ECCO} 2$ was accurate in its representation of all hydrographic fields at WOCE SR4, but only $\gamma^{\mathrm{n}}$ was acceptable at WOCE A12 (Table 3). Conversely, the RMSE criteria showed that CFSR was not accurate in representing any of the variables analyzed in any section (Table 3), with all of its RMSEs above the mean RMSE of the five reanalyses. However, the mean RMSE could be influenced by the CFSR results, given that CFSR does not assimilate the WOCE deep-ocean data. It is fairer to judge the accuracy of the reanalysis outputs without CFSR RMSE, because using this approach the four reanalyses compared assimilate WOCE data. When CFSR was not considered, the mean RMSE decreased, and ECMWF was no longer accurate for most of the hydrographic properties (Table 3). In this sense, only MyOcean could be considered to accurately represent all the hydrographic properties of the Weddell Sea. Table 3 also shows that the RMSE for salinity was higher in WOCE A12 than in WOCE SR4. This difference could be associated with more intense hydrodynamic processes occurring closest to the WOCE A12 section (e.g., 

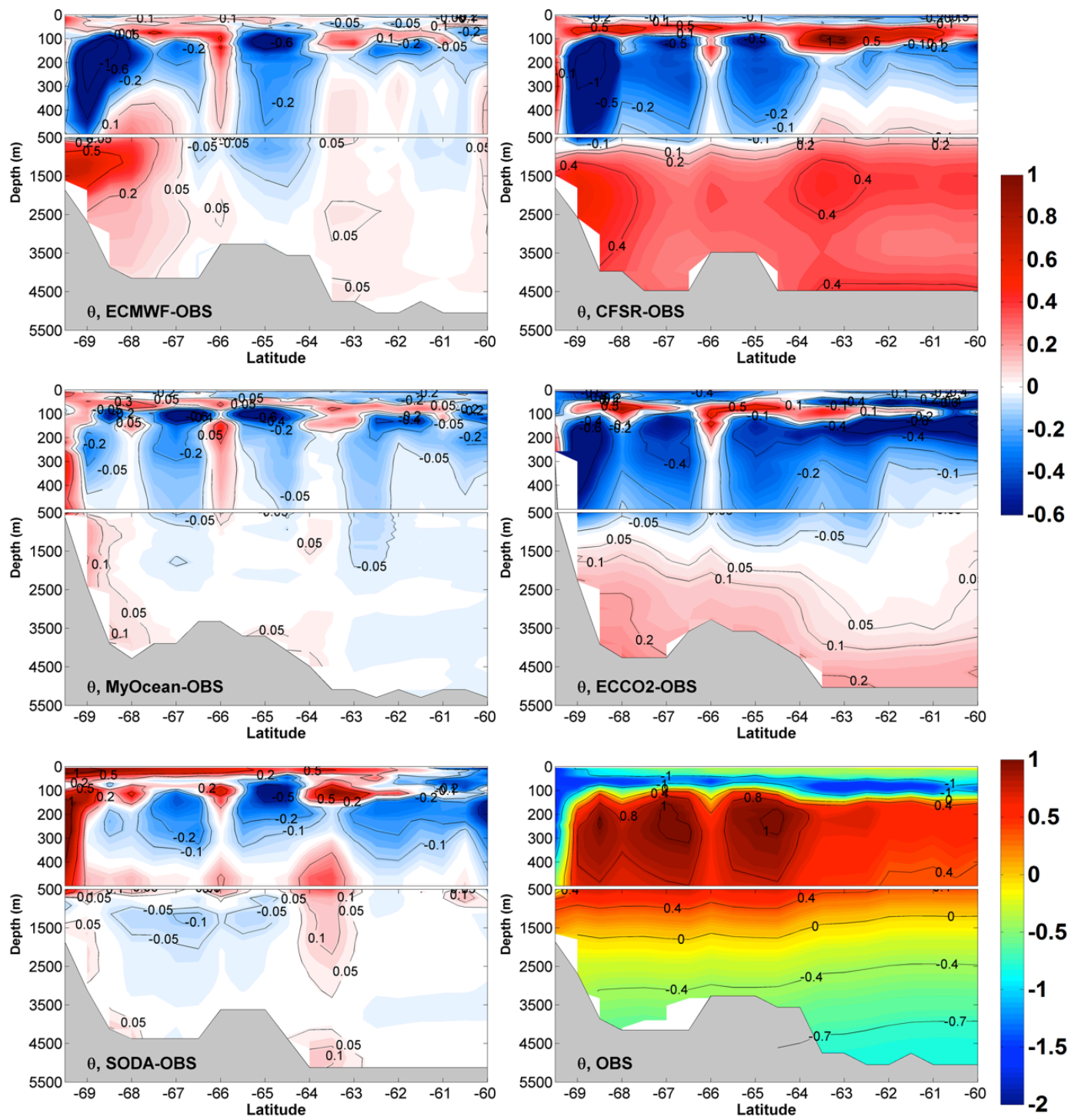

Figure 4. Section WOCE A12. Representation of the time-averaged in situ data and the differences between the reanalyzed and observed data for $\theta$. ECMWF, CFSR, MyOcean, ECCO2, and SODA results are indicated in each figure. The upper $500 \mathrm{~m}$ is expanded to show more detail.

Table 3. RMSE results used to evaluate the accuracy of the reanalyses, as established by Heuzé et al. (2013). The mean RMSEs of the five reanalyses assessed are in parentheses, and the mean RMSEs, considering all products except CFSR, are in italics. Reanalyses that have an RMSE lower than the mean RMSE are considered accurate in the intercomparison.

\begin{tabular}{|c|c|c|c|c|c|c|}
\hline & \multicolumn{3}{|c|}{ A12 } & \multicolumn{3}{|c|}{ SR4 } \\
\hline & $\begin{array}{r}\theta^{\circ} \mathrm{C} \\
(0.2838) \\
(0.2534)\end{array}$ & $\begin{array}{r}S \\
(0.2366) \\
(0.2288)\end{array}$ & $\begin{array}{r}\gamma^{\mathrm{n}} \mathrm{kg} \mathrm{m}^{-3} \\
(0.0779) \\
(0.0512)\end{array}$ & $\begin{array}{r}\theta^{\circ} \mathrm{C} \\
(0.2919) \\
(0.2794)\end{array}$ & $\begin{array}{r}S \\
(0.0995) \\
(0.0662)\end{array}$ & $\begin{array}{r}\gamma^{\mathrm{n}} \mathrm{kg} \mathrm{m}^{-3} \\
(0.1078) \\
(0.0631)\end{array}$ \\
\hline ECMWF & 0.2631 & 0.2101 & 0.0576 & 0.2977 & 0.0826 & 0.0768 \\
\hline CFSR & 0.4018 & 0.2676 & 0.1846 & 0.3420 & 0.2326 & 0.2421 \\
\hline MyOcean & 0.1704 & 0.2424 & 0.0325 & 0.1710 & 0.0533 & 0.0516 \\
\hline $\mathrm{ECCO} 2$ & 0.2889 & 0.2610 & 0.0701 & 0.2883 & 0.0647 & 0.0598 \\
\hline SODA & 0.2948 & 0.2018 & 0.0447 & 0.3606 & 0.0642 & 0.0608 \\
\hline
\end{tabular}



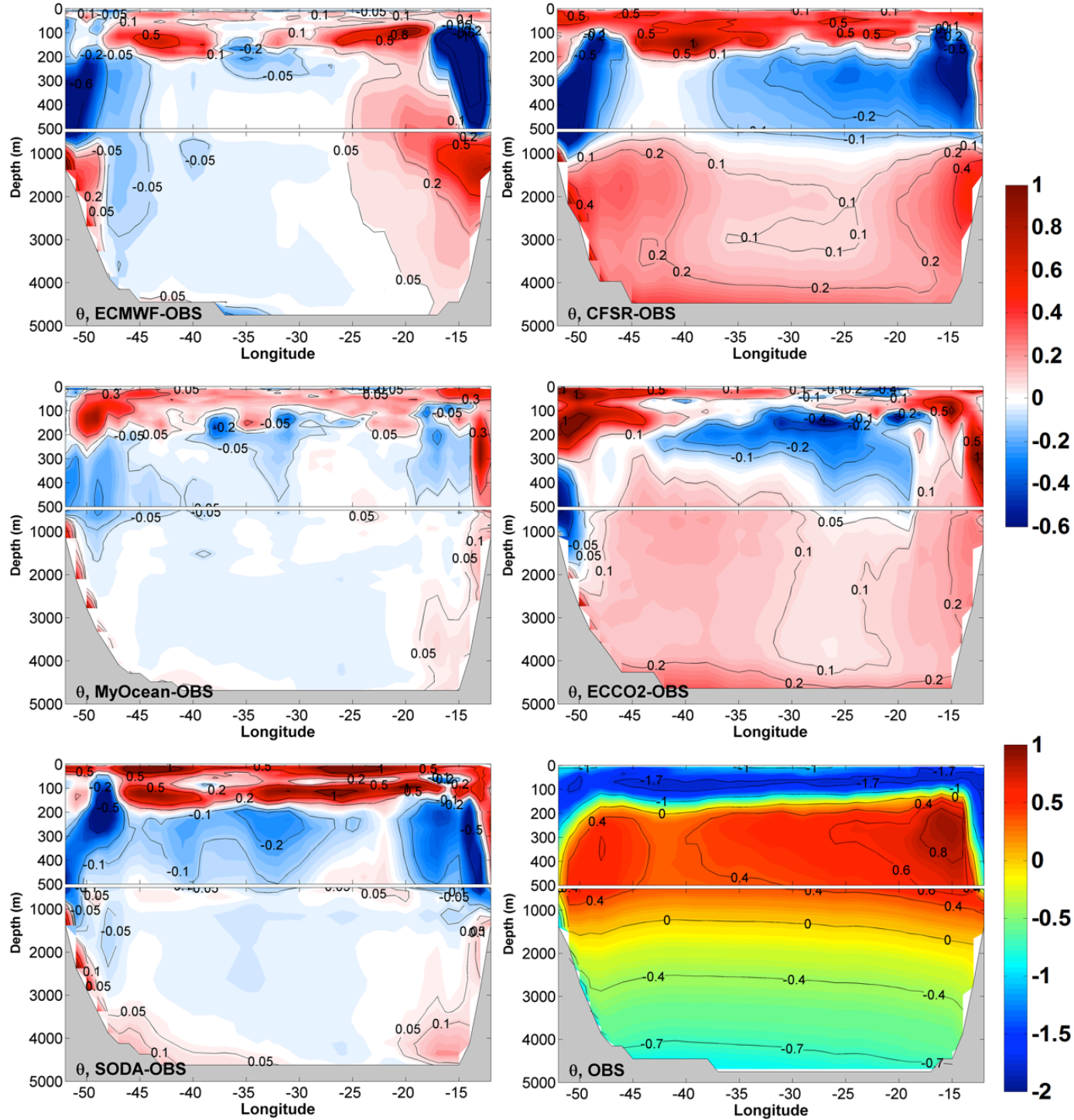

Figure 5. Same as in Fig. 4, but for section WOCE SR4.

Klatt et al., 2005) than in WOCE SR4, implying that that region is more sensitive to changes in the water column structure. The dynamic impacts on the three dimensional oceanic flow field all the way up through the water column is accentuated by the presence of the Maud Rise seamount (Holland, 2001). In less dynamic regions - e.g., WOCE SR4 (which is dampened by the Weddell Gyre circulation) - most of the reanalysis methods were able to represent the $S$ field, including MyOcean and ECCO2, despite not meeting the accuracy criteria for WOCE A12. We also evaluated the representation of the hydrographic properties of each reanalysis using a more robust statistical analysis through the standardized Taylor diagram (Fig. 10).

Generally, all of the ocean reanalysis products evaluated in this study represented the $\gamma^{\mathrm{n}}$ and $\theta$ fields better than the $S$ field throughout the water column in both sections
(Fig. 10). In WOCE A12, a good representation of the $\gamma^{\mathrm{n}}$ field was correlated with a good representation of the $\theta$ field (Fig. 10a), whereas in WOCE SR4, both the $S$ and $\theta$ reanalysis fields were responsible for good $\gamma^{\mathrm{n}}$ statistical measurements (Fig. 10b).

In the WOCE A12 section (Fig. 10a), the reanalysis systems that gave results closest to the reference point were MyOcean and SODA, both with CRMSEs of less than 0.25 and correlation coefficients $(r \mathrm{~s})$ of 0.99 for $\gamma^{\mathrm{n}}$. ECMWF and ECCO2 had CRMSEs of $\sim 0.25$ and $r$ s of $\sim 0.97$; however, the former system had a slightly better $r$ and a normalized standard deviation of $\sim 1$, which implied that ECMWF provides a better representation than $\mathrm{ECCO}$. For $\theta$, MyOcean was also close to the reference (CRMSE $\sim 0.25$ and $r>0.95$ ), but followed by ECMWF and then ECCO2 and SODA. The MyOcean product was the closest to the 

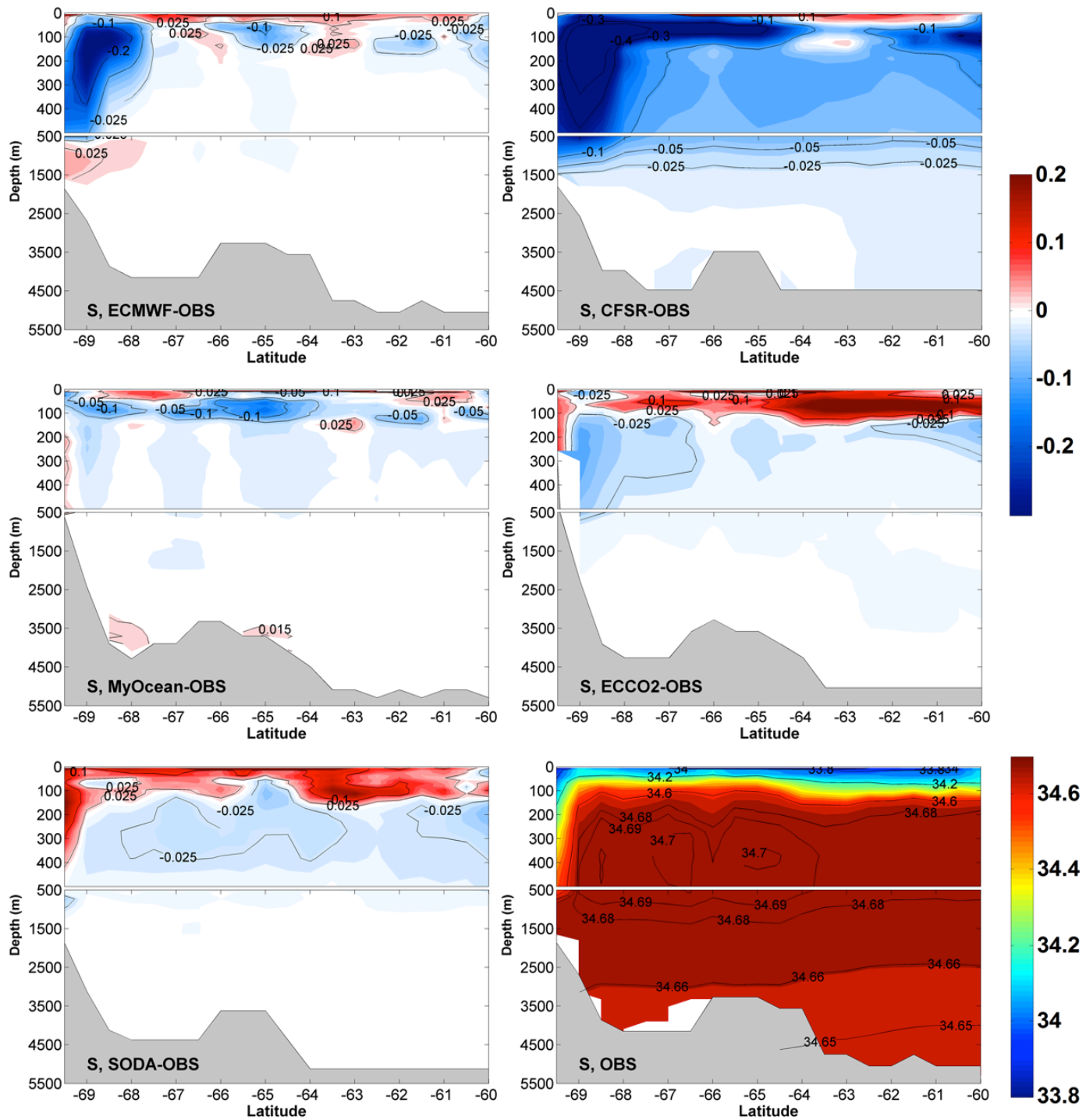

Figure 6. Section WOCE A12. Representation of the time-averaged in situ data and the differences between the reanalyzed and observed data for $S$. ECMWF, CFSR, MyOcean, ECCO2, and SODA results are indicated in each figure. The upper $500 \mathrm{~m}$ is expanded to show more detail.

reference for salinity (CRMSE $\sim 0.60$ and $r \sim 0.80$ ), followed by ECMWF and SODA. For all fields, the CFSR product was the furthest from the reference point in this section.

In WOCE SR4 (Fig. 10b), MyOcean produced the closest reanalysis results to the reference, with a CRMSE $<0.25$ and $r \sim 0.98$ for all fields. In this section, ECCO2 had CRMSE $<0.32$ and $r>0.94$ for all hydrographical properties, which made it the second most accurate reanalysis system. SODA showed $\gamma^{\mathrm{n}}$ and $S$ fields closer to the reference point than ECMWF; however, $\theta$ in the latter reanalysis had a better CRMSE and $r$ than in the first system. As for WOCE A12, CFSR was the furthest from the reference point (except for $\theta$ ). CFSR showed a good $\theta$ distribution pattern (Fig. 10), although it had significant differences in absolute values (Figs. 5, 7, 9).

\subsection{Variability and trends in deep water masses}

Ocean reanalysis products are powerful tools that can be used in climate studies because of their generally high temporal resolution. To make use of this property, we also assessed the temporal variability and trends of the deep water masses represented by each reanalysis product.

\subsubsection{Warm Deep Water}

Most of the reanalysis systems evaluated represented the WDW layer $\left(28.1 \leq \gamma^{\mathrm{n}}<28.27 \mathrm{~kg} \mathrm{~m}^{-3}\right)$ as warmer and saltier in WOCE A12 (Fig. 11) than in WOCE SR4 (Fig. 12). This difference occurs because WDW advection towards the inner Weddell Sea is associated with cooling and freshening 

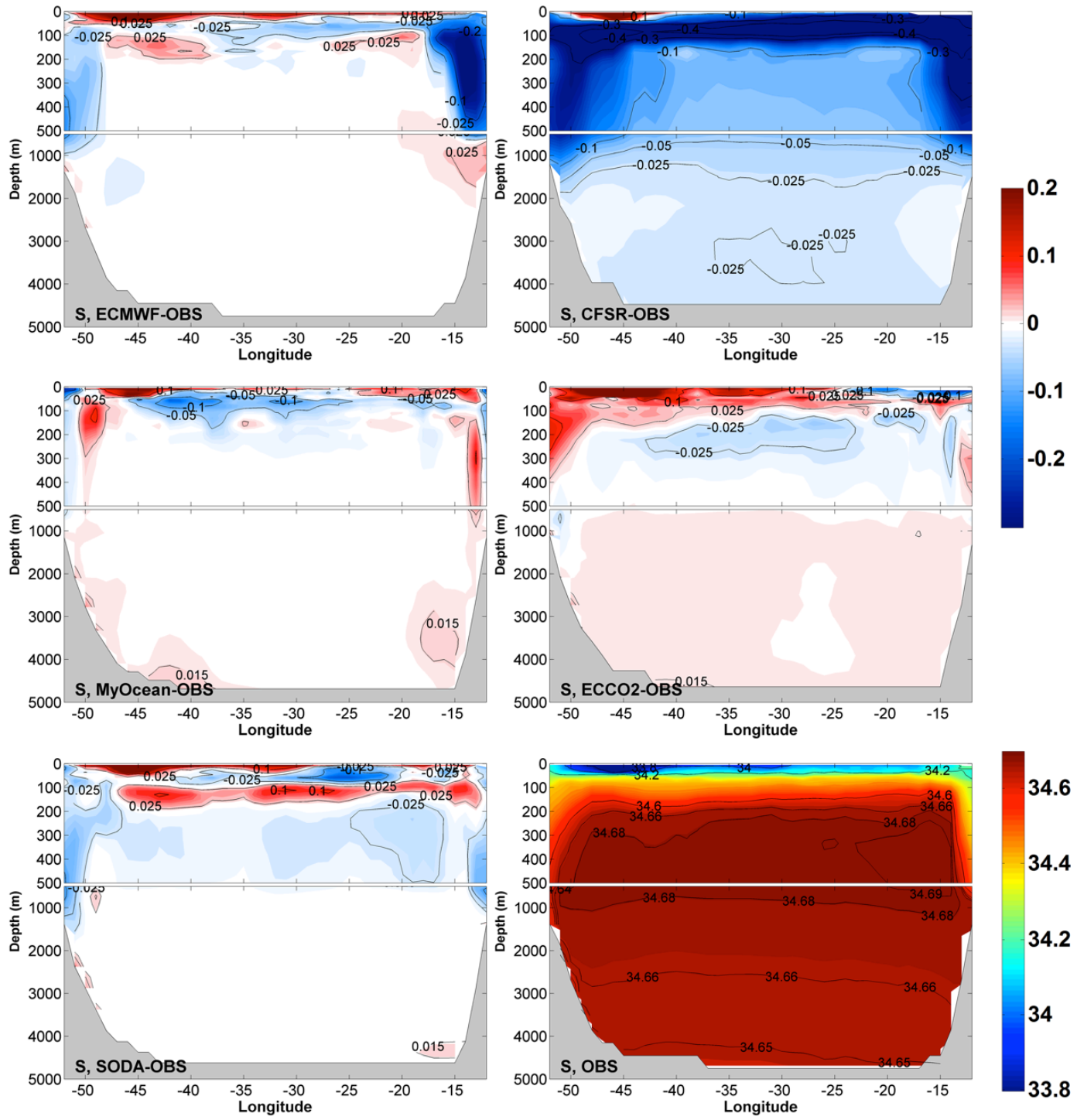

Figure 7. Same as in Fig. 6, but for section WOCE SR4.

of this water mass through mixing processes with upper waters (e.g., Schröder and Fahrbach, 1999). Moreover, the differences between A12 and SR4 support that the mixing processes along the WDW pathway are being captured by most of the reanalysis products.

The ECMWF, MyOcean and ECCO2 $\theta$ and $S$ fields showed a decreasing trend for both of the areas analyzed during the following periods: 1980-2011, 1993-2004, and 1992-2004 (Table 4). These trends were observed clearly beyond the 1990s. Although MyOcean and ECCO2 had hydrographic fields represented until 2010, here they were only evaluated until 2004 because of the anomalous variability observed in both reanalysis systems beyond 2004 (Figs. 11, 12). ECCO 2 showed a clearly negative trend in $\theta$ and $S$ in both sections, which began in the second half of the 1990s and intensified beyond 2004 (Figs. 11, 12) due the opening of an oceanic polynya near the prime meridian that led to injection of dense water directly at great depths (Azaneu et al., 2014). In contrast, SODA showed increasing trends of $\theta$ and $S$ (1980-2010) for this water mass in both sections, although these trends were not statistically significant at WOCE A12 (Table 4). In addition, this was the only reanalysis that captured a significant decreasing trend in the $\gamma^{\mathrm{n}}$ field throughout the period analyzed, which was associated with its increased potential temperature in section WOCE SR4 (Table 4). SODA also showed a marked temporal variability in $\gamma^{\mathrm{n}}$ throughout the entire series (Figs. 11, 12).

\subsubsection{Weddell Sea Deep Water}

The ECMWF reanalysis product showed a stable period in the WOCE A12 section between 1987 and 2007 (Fig. 13), 

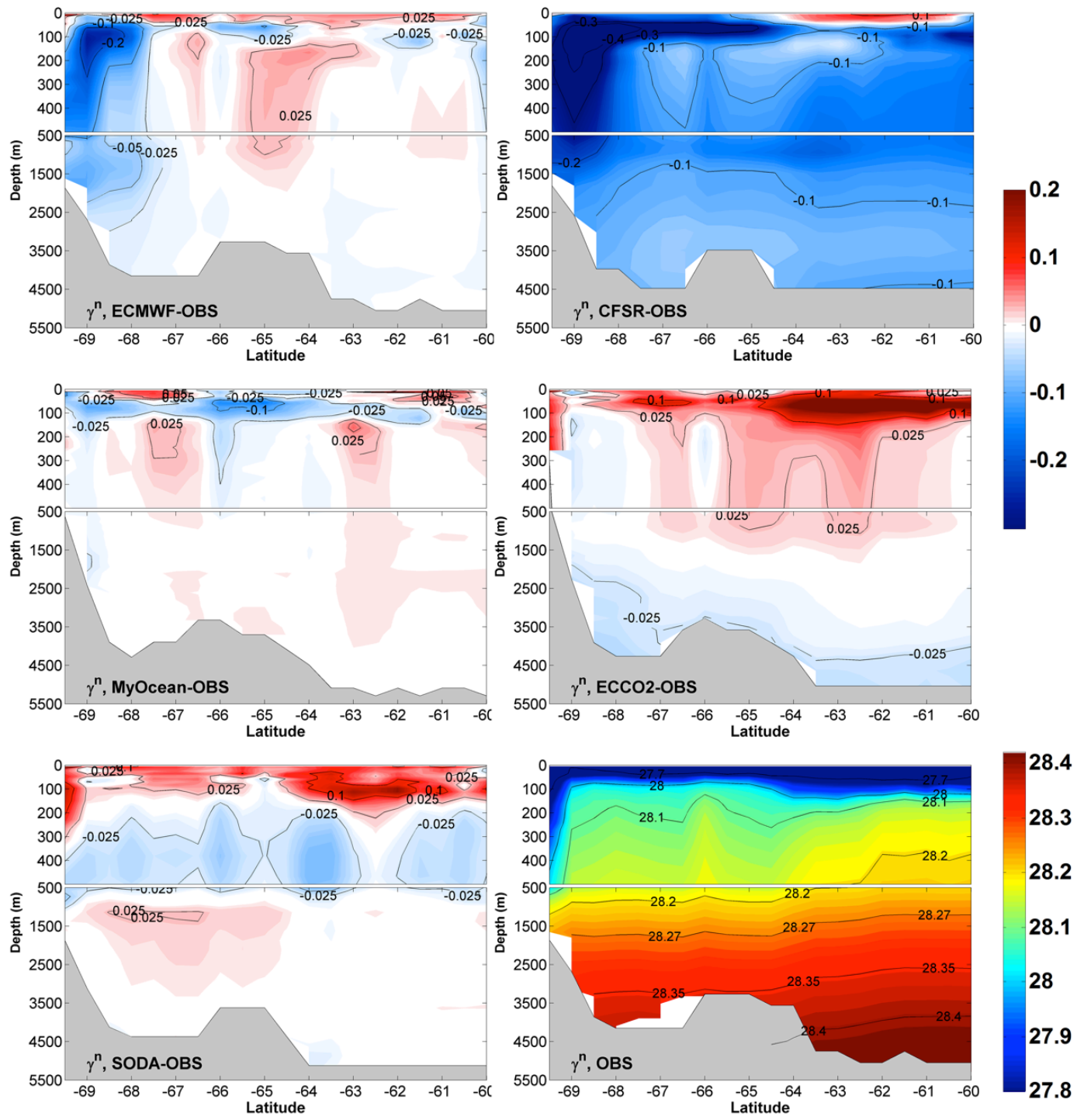

Figure 8. Section WOCE A12. Representation of the time-averaged in situ data and the differences between the reanalyzed and observed data for $\gamma^{\mathrm{n}}$. ECMWF, CFSR, MyOcean, ECCO2, and SODA results are indicated in each figure. The upper $500 \mathrm{~m}$ is expanded to show more detail.

whereas before 1987 and after 2007, anomalous variability patterns were observed; in WOCE SR4, ECMWF showed low levels of variability throughout the entire period (Fig. 14). The MyOcean and ECCO2 products showed an anomalous period after 2004 in both sections (Figs. 13, 14). These anomalous periods in ECMWF (in section WOCE A12), MyOcean and ECCO2 were not considered when we calculated the trends for the hydrographic properties of the WSDW layer $\left(28.27 \leq \gamma^{\mathrm{n}}<28.4 \mathrm{~kg} \mathrm{~m}^{-3}\right)$.

ECMWF, MyOcean and SODA showed cooling, freshening and increasing density trends in section WOCE A12 (Fig. 13) for the periods 1987-2007, 1993-2004 and 19802010, respectively (Table 4). For 2000-2007, ECMWF showed a decline in $\gamma^{\mathrm{n}}$ that was associated with its increasing $\theta$. In the same period, $S$ also exhibited a slight increase that could also be observed in the in situ data (Fig. 13). In contrast, ECCO2 showed warming, freshening and lightening trends for the same section from 1992 to 2004 (Fig. 13) although only the $S$ trend was statistically significant (Table 4).

In WOCE SR4 (Fig. 14), ECMWF and SODA showed cooling and freshening trends (Table 4), with the former unveiling a lightening trend and the latter showing the opposite pattern. In this section, there was a colder and fresher pattern in 2008 that was only captured in ECMWF, but it was intensified in comparison to the observations (Fig. 14). The MyOcean and ECCO2 products showed warming, increasing salinity and lightening trends until 2004 (Table 4), but only the latter reanalysis had significant results. After 2005, 

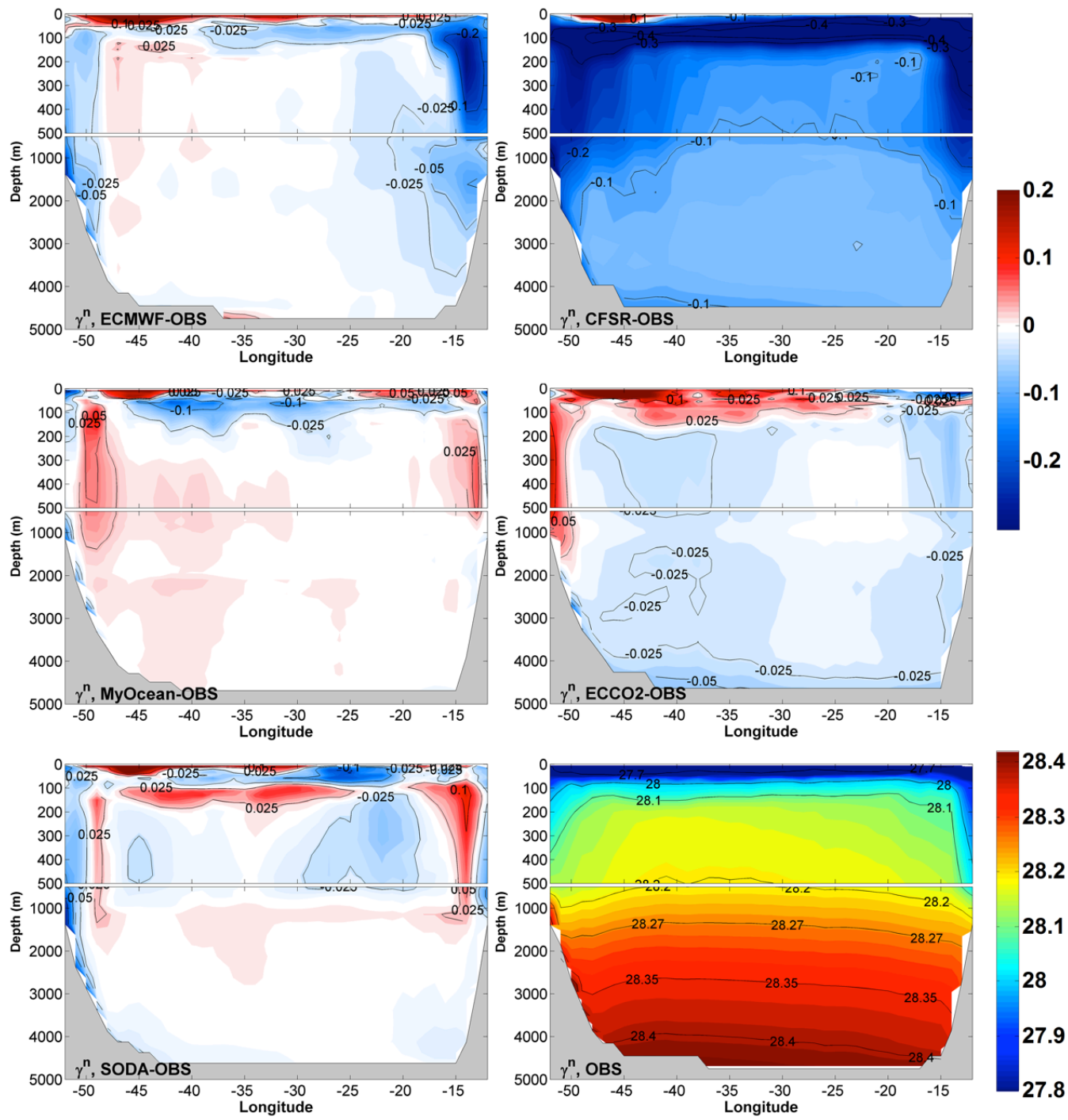

Figure 9. Same as in Fig. 8, but for section WOCE SR4.
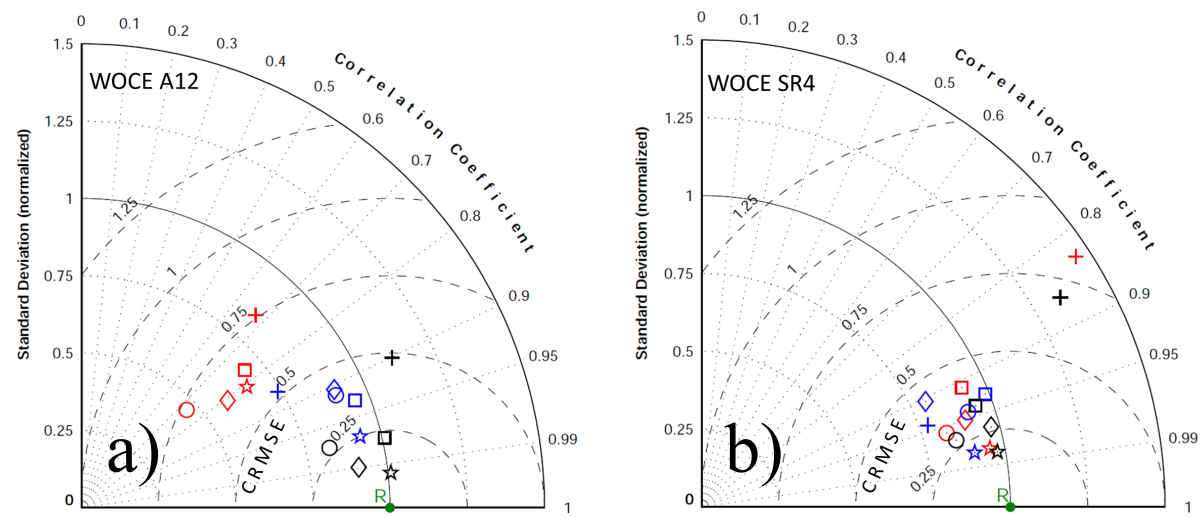

$\square \mathrm{ECMWF}+\mathrm{CFSR}$ it MyOcean OECCO2 $\diamond \mathrm{SODA}$

Figure 10. Taylor diagrams of sections WOCE A12 (a) and WOCE SR4 (b). $\theta$ (blue), $S$ (red), and $\gamma^{\mathrm{n}}$ (black). ECMWF (square), CFSR (plus sign), MyOcean (pentagram), ECCO2 (circle), and SODA (diamond). Observed data serve as a reference (green R). 

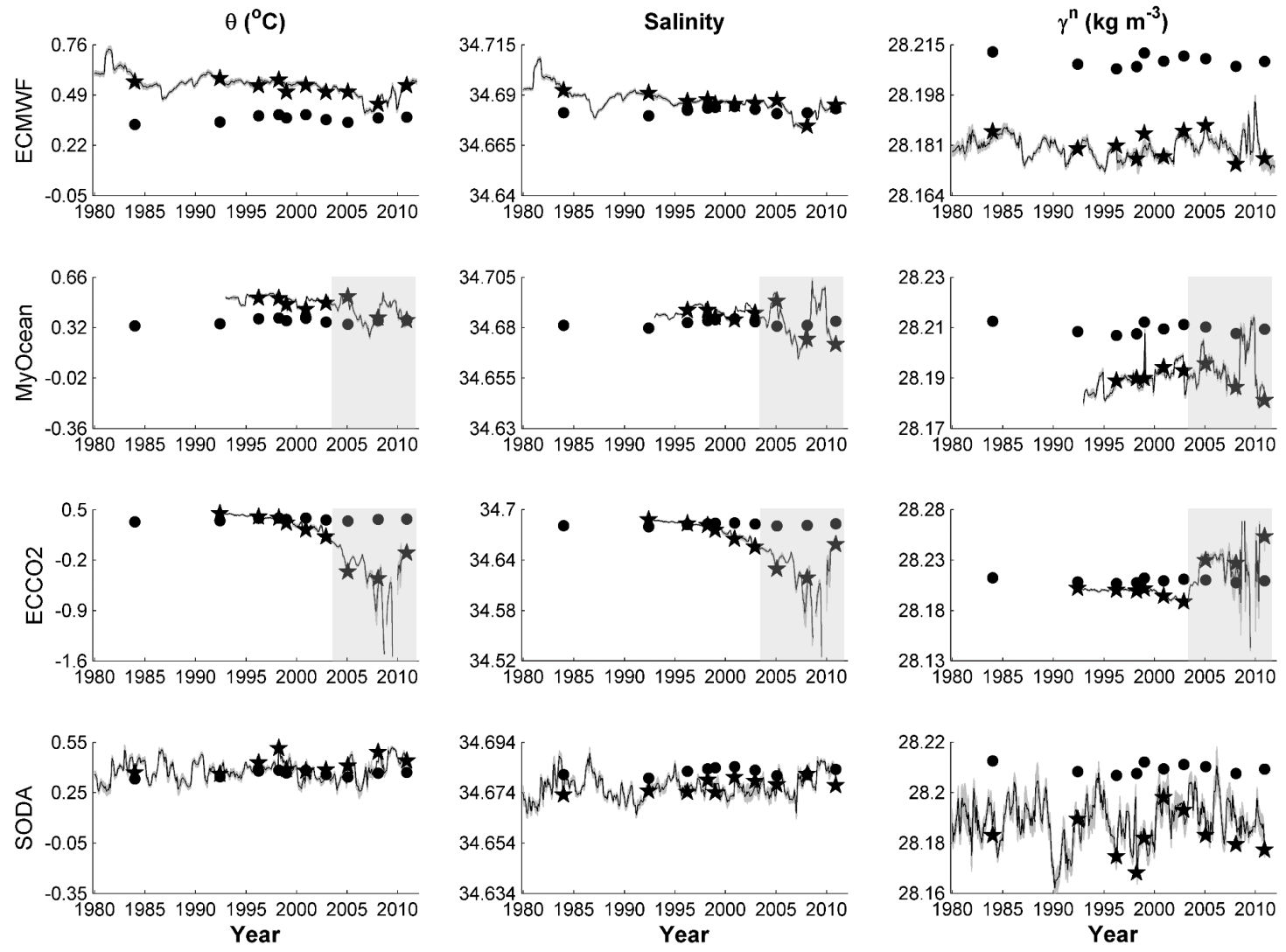

Figure 11. Time series of monthly mean hydrographic properties of WDW in ECMWF, MyOcean, ECCO2, and SODA (top to bottom) averaged along the WOCE A12 section line. From left to right: $\theta, S$, and $\gamma^{\mathrm{n}}$. The gray shading indicates the standard deviation due to variation caused by the different station locations in the different years of the hydrographic cruises. The dots indicate the values derived from the observed data, and the pentagrams are the values from the corresponding reanalysis data. Note that the scales are different to show the variability in the time series. The gray rectangles denote the period in which the hydrographic properties showed anomalous variability.

an anomalous cooling and freshening occurred in ECCO2 in response to a polynya that opened in the Weddell Sea (Azaneu et al., 2014), and WSDW increased in density (Figs. 13, 14).

\subsubsection{Weddell Sea Bottom Water}

For WSBW $\left(\gamma^{\mathrm{n}} \geq 28.4 \mathrm{~kg} \mathrm{~m}^{-3}\right)$, ECMWF revealed a warming trend beyond the second half of the 1990s (Figs. 15, 16). However, when the entire period (1980-2011) was considered, a cooling trend was observed in both sections (Table 4). In addition, ECMWF exhibited a freshening trend throughout the entire period (Table 4; Figs. 15, 16). In section WOCE SR4 (Fig. 16), ECMWF also modeled 2008 as a year subject to cooling and freshening, which was also observed in the in situ data. The $\gamma^{\mathrm{n}}$ decreased in both sections throughout the entire period (Table 4) and was clearly observed beyond the 1990s (Figs. 15, 16).

The MyOcean product showed an increasing trend in $\theta$ and $S$ and an opposite trend in $\gamma^{\mathrm{n}}$ in the 1993-2010 period in WOCE A12 (Table 4). Its WSBW annual mean results were similar to the in situ data (Figs. 15, 16). In WOCE SR4 (Fig. 16), there was an anomalous increase in all hydrographic properties after 2010. In the period 1993-2009, the MyOcean reanalysis showed warming and lightning trends (Table 4).

SODA's monthly mean values were clearly warmer and saltier than those observed by in situ data (Figs. 15, 16). In section WOCE A12 (Fig. 15), $\theta$ and $S$ exhibited an increasing trend throughout the 1980-2010 period, and a decrease in $\gamma^{\mathrm{n}}$ was observed (Table 4). However, in section WOCE SR4 (Fig. 16), only $S$ had a statistically significant trend, indicating long-term freshening.

\section{Discussion and conclusions}

The ocean reanalysis products evaluated here (ECMWF, CFSR, MyOcean, ECCO2 and SODA) have few common characteristics. Instead, their ocean models, spatial resolutions (both horizontal and vertical), assimilation methods, observed data sets being assimilated, couplings with sea-ice models, and physics applied to ocean and sea-ice models all 

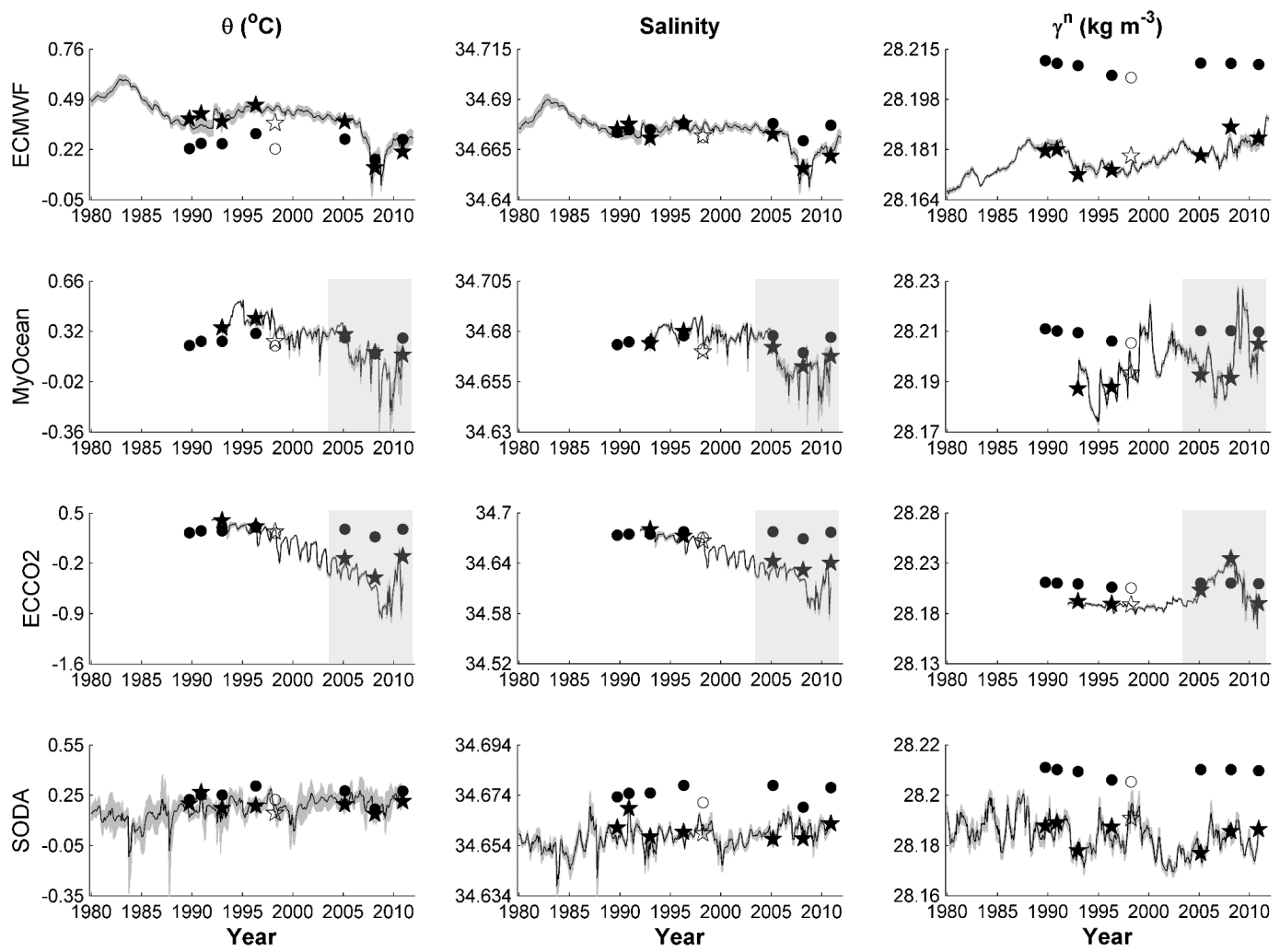

Figure 12. Time series of monthly mean hydrographic properties of WDW in ECMWF, MyOcean, ECCO2, and SODA (top to bottom) averaged along the WOCE SR4 section line. From left to right: $\theta, S$, and $\gamma^{\mathrm{n}}$. The gray shading indicates the standard deviation due to variation caused by the different station locations in the different years of the hydrographic cruises (excluding the set of stations of 1998). The dots indicate the values derived from the observed data, and the pentagrams are the values from the corresponding reanalysis data. The filled markers denote full sections, and the open markers denote section 1998, which does not extend over the entire eastern margin of the Weddell Sea. Note that the scales are different to show the variability in the time series. The gray rectangles denote the period in which the hydrographic properties showed anomalous variability.

differ (Table 1). Thus, the evaluation of some features can be represented in distinct ways because the ocean model dynamics can respond to different assimilations procedures, parameterizations, and initial forcing fields (Figs. 2-9). For example, all of the reanalyses represented the inflow/outflow cores of WDW in the WOCE SR4 repeat section, but the core average depths, shapes and spatial extensions differed among all of the products evaluated (not shown). It is important to evaluate the ocean reanalysis systems because if some common biases exist, dynamically complex regions will be difficult to capture in the ocean models.

Moreover, it is important to highlight that the WOCE data set cannot be considered a fully independent test of the reanalysis products because this data set is assimilated during the simulation phase by most of the models. In this sense, it is reasonable that CFSR deviates from the WOCE observations much more than any of the other products (Figs. 2-9). However, in the absence of any independent observations, the WOCE data set remains the best choice for such evaluation because of its comprehensive nature, high resolution and the representativeness of the Weddell Sea water mass structure and spatial distribution.

The ocean surface layer was the location of the major differences among the ocean reanalysis products (Figs. 4-9). A good representation of the surface ocean is vital for climate studies, but even the products coupled with a sea-ice model (i.e., CFSR, MyOcean, and ECCO2) did not correctly represent the surface properties. The errors in the representation of surface water can also be observed in the $\theta-S$ diagrams (Figs. 2, 3) and may be consequences of the difficulties faced when reproducing the complex processes acting on the surface ocean, such as the processes and fluxes at the air-sea and ice-ocean interfaces. One exception to this trend in misfit was the MyOcean reanalysis, which provided similar levels of variability in hydrographic properties compared to the observations in both sections, despite the persistence of differences in the absolute values.

In contrast to the representations of the surface layer, the deep-ocean representations deviated less from the observed data in terms of absolute values (Figs. 2-9). In this layer, the ECMWF, MyOcean and SODA products provided the most 
Table 4. Linear fits and confidence bounds (95\% confidence) of the annual time series of hydrographic properties. Bold font indicates a statistically significant trend $(P \leq 0.05)$. The period considered to determine the trends depends on the water mass in each reanalysis.

\begin{tabular}{|c|c|c|c|c|c|}
\hline & & & WDW & WSDW & WSBW \\
\hline \multirow{16}{*}{ WOCE A12 } & \multirow{4}{*}{ ECMWF } & Period of the trend & 1980-2011 & 1987-2007 & 1980-2011 \\
\hline & & $\theta\left({ }^{\circ} \mathrm{C} \mathrm{yr}^{-1}\right)$ & $-\mathbf{0 . 0 0 4 0}( \pm 0.0016)$ & $-\mathbf{0 . 0 0 5 2}( \pm 0.0021)$ & $-\mathbf{0 . 0 0 0 9}( \pm 0.0003)$ \\
\hline & & $S\left(\mathrm{yr}^{-1}\right)$ & $\mathbf{- 0 . 0 0 0 4}( \pm 0.0001)$ & $-\mathbf{0 . 0 0 0 6}( \pm 0.0002)$ & $-\mathbf{0 . 0 0 0 3}( \pm 0.00004)$ \\
\hline & & $\gamma^{\mathrm{n}}\left(\mathrm{kg} \mathrm{m}^{-3} \mathrm{yr}^{-1}\right)$ & $-0.0001( \pm 0.0001)$ & $+\mathbf{0 . 0 0 0 3}( \pm 0.0002)$ & $-\mathbf{0 . 0 0 0 1}( \pm 0.00003)$ \\
\hline & \multirow{4}{*}{ MyOcean } & Period of the trend & 1993-2004 & 1993-2004 & 1993-2010 \\
\hline & & $\theta\left({ }^{\circ} \mathrm{C} \mathrm{yr}^{-1}\right)$ & $-0.0033( \pm 0.0041)$ & $-\mathbf{0 . 0 0 2 2}( \pm 0.0017)$ & $+\mathbf{0 . 0 0 2 2}( \pm 0.0003)$ \\
\hline & & $S\left(\mathrm{yr}^{-1}\right)$ & $-0.0001( \pm 0.0004)$ & $-\mathbf{0 . 0 0 0 2}( \pm 0.0002)$ & $+\mathbf{0 . 0 0 0 2}( \pm 0.0001)$ \\
\hline & & $\gamma^{\mathrm{n}}\left(\mathrm{kg} \mathrm{m}^{-3} \mathrm{yr}^{-1}\right)$ & $+\mathbf{0 . 0 0 0 9}( \pm 0.0005)$ & $+\mathbf{0 . 0 0 0 2}( \pm 0.0002)$ & $-\mathbf{0 . 0 0 0 3}( \pm 0.0001)$ \\
\hline & \multirow{4}{*}{$\mathrm{ECCO} 2$} & Period of the trend & 1992-2004 & 1992-2004 & - \\
\hline & & $\theta\left({ }^{\circ} \mathrm{Cyr}^{-1}\right)$ & $\mathbf{- 0 . 0 3 7 4}( \pm 0.0120)$ & $+0.0003( \pm 0.0019)$ & - \\
\hline & & $S\left(\mathrm{yr}^{-1}\right)$ & $-\mathbf{0 . 0 0 3 2}( \pm 0.0007)$ & $-\mathbf{0 . 0 0 0 2}( \pm 0.00007)$ & - \\
\hline & & $\gamma^{\mathrm{n}}\left(\mathrm{kg} \mathrm{m}^{-3} \mathrm{yr}^{-1}\right)$ & $+0.0002( \pm 0.0012)$ & $-0.0004( \pm 0.0004)$ & - \\
\hline & \multirow{4}{*}{ SODA } & Period of the trend & 1980-2010 & 1980-2010 & 1980-2010 \\
\hline & & $\theta\left({ }^{\circ} \mathrm{C} \mathrm{yr}^{-1}\right)$ & $+0.0010( \pm 0.0020)$ & $-\mathbf{0 . 0 0 0 5}( \pm 0.0004)$ & $+\mathbf{0 . 0 0 0 1}( \pm 0.0001)$ \\
\hline & & $S\left(\mathrm{yr}^{-1}\right)$ & $+0.0001( \pm 0.0002)$ & $-0.00001( \pm 0.00003)$ & $+\mathbf{0 . 0 0 0 0 1}( \pm 0.000004)$ \\
\hline & & $\gamma^{\mathrm{n}}\left(\mathrm{kg} \mathrm{m}^{-3} \mathrm{yr}^{-1}\right)$ & $+0.0001( \pm 0.0003)$ & $+\mathbf{0 . 0 0 0 1}( \pm 0.00004)$ & $-\mathbf{0 . 0 0 0 0 2}( \pm 0.00002)$ \\
\hline \multirow{16}{*}{ WOCE SR4 } & \multirow{4}{*}{ ECMWF } & Period of the trend & 1980-2011 & 1980-2011 & 1980-2011 \\
\hline & & $\theta\left({ }^{\circ} \mathrm{Cyr}^{-1}\right)$ & $-\mathbf{0 . 0 0 8 0}( \pm 0.0026)$ & $-0.0004( \pm 0.0006)$ & $-\mathbf{0 . 0 0 0 5}( \pm 0.0003)$ \\
\hline & & $S\left(\mathrm{yr}^{-1}\right)$ & $-\mathbf{0 . 0 0 0 6}( \pm 0.0002)$ & $\mathbf{- 0 . 0 0 0 1}( \pm 0.00005)$ & $\mathbf{- 0 . 0 0 0 2}( \pm 0.00004)$ \\
\hline & & $\gamma^{\mathrm{n}}\left(\mathrm{kg} \mathrm{m}^{-3} \mathrm{yr}^{-1}\right)$ & $+\mathbf{0 . 0 0 0 3}( \pm 0.0001)$ & $-0.0001( \pm 0.0001)$ & $-\mathbf{0 . 0 0 0 2}( \pm 0.00005)$ \\
\hline & \multirow{4}{*}{ MyOcean } & Period of the trend & 1993-2004 & 1993-2004 & 1993-2009 \\
\hline & & $\theta\left({ }^{\circ} \mathrm{C} \mathrm{yr}^{-1}\right)$ & $\mathbf{- 0 . 0 1 2 7}( \pm 0.0100)$ & $+0.0014( \pm 0.0051)$ & $+\mathbf{0 . 0 0 1 4}( \pm 0.0010)$ \\
\hline & & $S\left(\mathrm{yr}^{-1}\right)$ & $-0.0002( \pm 0.0004)$ & $+0.0001( \pm 0.0004)$ & $-0.00002( \pm 0.0001)$ \\
\hline & & $\gamma^{\mathrm{n}}\left(\mathrm{kg} \mathrm{m}^{-3} \mathrm{yr}^{-1}\right)$ & $+\mathbf{0 . 0 0 1 8}( \pm 0.0012)$ & $-0.00005( \pm 0.0005)$ & $-\mathbf{0 . 0 0 0 4}( \pm 0.0001)$ \\
\hline & \multirow{4}{*}{$\mathrm{ECCO} 2$} & Period of the trend & 1992-2004 & 1992-2004 & - \\
\hline & & $\theta\left({ }^{\circ} \mathrm{C} \mathrm{yr}^{-1}\right)$ & $-\mathbf{0 . 0 5 1 6}( \pm 0.0062)$ & $+\mathbf{0 . 0 0 4 9}( \pm 0.0016)$ & - \\
\hline & & $S\left(\mathrm{yr}^{-1}\right)$ & $-\mathbf{0 . 0 0 3 8}( \pm 0.0003)$ & $+\mathbf{0 . 0 0 0 3}( \pm 0.0001)$ & - \\
\hline & & $\gamma^{\mathrm{n}}\left(\mathrm{kg} \mathrm{m}^{-3} \mathrm{yr}^{-1}\right)$ & $+0.0001( \pm 0.0004)$ & $\mathbf{- 0 . 0 0 0 8}( \pm 0.0002)$ & - \\
\hline & \multirow{4}{*}{ SODA } & Period of the trend & 1980-2010 & 1980-2010 & 1980-2010 \\
\hline & & $\theta\left({ }^{\circ} \mathrm{C} \mathrm{yr}^{-1}\right)$ & $+\mathbf{0 . 0 0 4 1}( \pm 0.0014)$ & $-\mathbf{0 . 0 0 0 3}( \pm 0.0003)$ & $-0.0001( \pm 0.0001)$ \\
\hline & & $S\left(\mathrm{yr}^{-1}\right)$ & $+\mathbf{0 . 0 0 0 2}( \pm 0.0001)$ & $-0.00001( \pm 0.00003)$ & $-\mathbf{0 . 0 0 0 0 1}( \pm 0.00001)$ \\
\hline & & $\gamma^{\mathrm{n}}\left(\mathrm{kg} \mathrm{m}^{-3} \mathrm{yr}^{-1}\right)$ & $-\mathbf{0 . 0 0 0 3}( \pm 0.0002)$ & $+\mathbf{0 . 0 0 0 1}( \pm 0.00004)$ & $+0.00001( \pm 0.00001)$ \\
\hline
\end{tabular}

accurate absolute values among all of the reanalyses evaluated. Considering the hydrographic properties analyzed, $\gamma^{\mathrm{n}}$ was best represented for all of the reanalyses, which reflects the fact that $\theta$ and $S$ can compensate for each other to better represent the deep layers in ocean reanalysis products (Fig. 10). Kerr et al. (2012b) reported a good representation of the deep ocean structure and water mass contribution in the Weddell Sea and Weddell-Scotia Confluence through an investigation of the earlier version of the SODA product (version 1.4.2). The same authors reported that SODA version 1.4.2 represented the $S$ field for the deep ocean poorly. The SODA product version 2.2.4 analyzed here showed an improved $S$ field due to some modifications from the previous version (e.g., an increase in assimilated salinity data).
The horizontal resolution among the ocean reanalyses evaluated here varied from $1^{\circ}$ (e.g., ECMWF) to $1 / 4^{\circ}$ (e.g., ECCO2 and MyOcean; Table 1). Although increased horizontal resolution is important to better simulate hydrographic representations, we highlight that improvements in parameterization, such as advection schemes and subgrid-scale mixing processes, may have as much impact on the reanalyses as modest increases in horizontal resolution (e.g., Renner et al., 2009). For example, for the deep layers, the ECCO 2 product $\left(1 / 4^{\circ}\right)$ had greater differences in absolute values (in relation to the in situ data) than the ECMWF product ( $1^{\circ}$; Figs. $\left.2-9\right)$. One must examine the model biases (because the deep ocean layers are normally poorly sampled) and assimilation methods used. Furthermore, as reported by Dee (2005), all data 

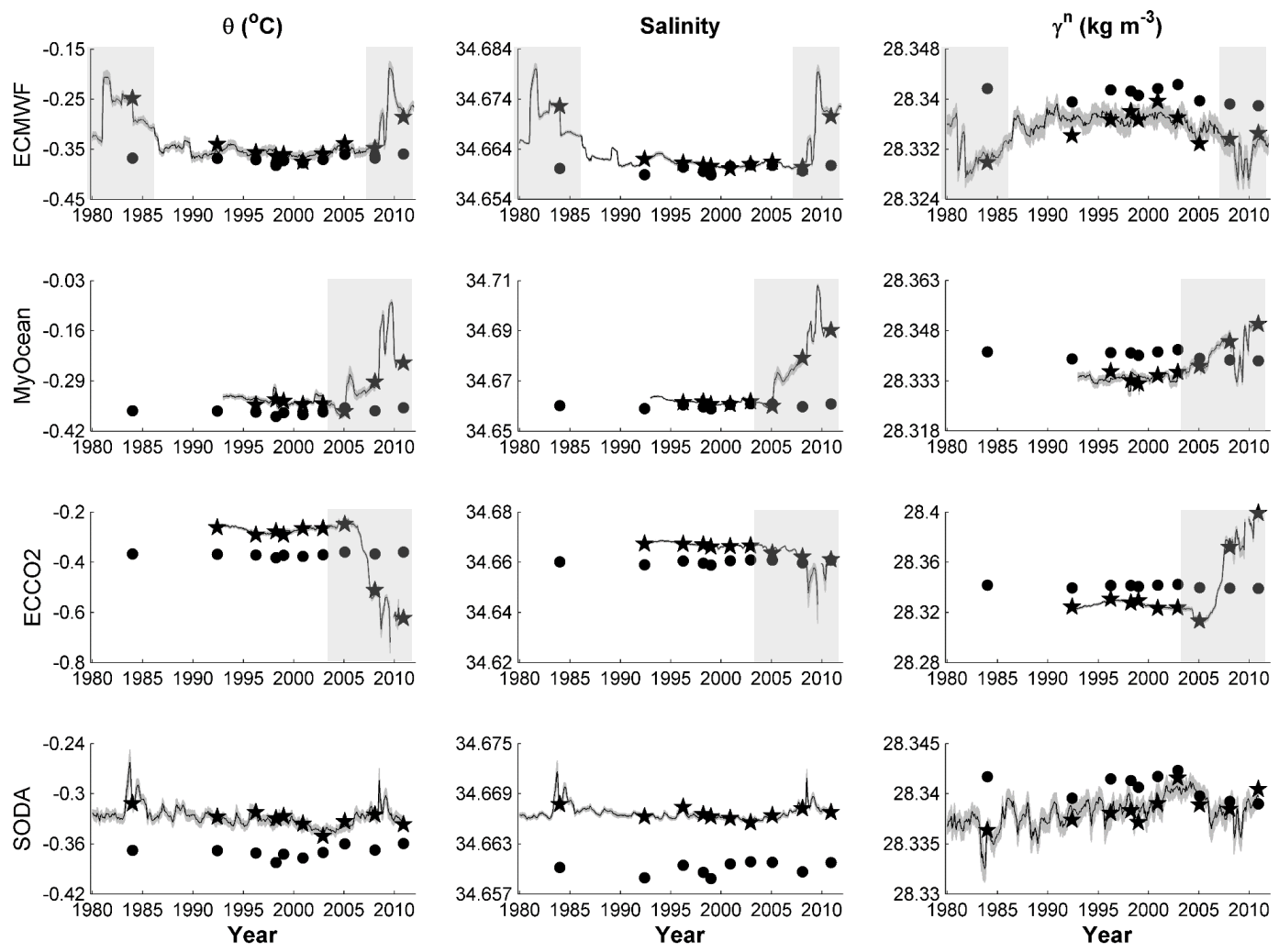

Figure 13. Same as in Fig. 11, but for WSDW.

assimilation systems are affected by systematic errors associated with the following: (i) problems with input data, (ii) approximations relative to the in situ observations, (iii) limitations of the assimilating models, and (iv) the assimilation methodology itself. Because these errors are intrinsic to each reanalysis, our validation could have been biased by at least one of these points. Moreover, comprehensive data quality control before data assimilation is an essential step in assessing reanalysis quality. In fact, increasing the deep-ocean observations available for assimilation by ocean reanalysis products is required to better represent this region of the oceans.

Three of the five reanalysis products evaluated here were coupled with sea-ice models (i.e., CFSR, MyOcean, and ECCO2). Coupling with a sea-ice model is essential for reproducing the deep-water properties in ocean circulation models (e.g., Kerr et al., 2009b) because both dynamic and thermodynamic sea-ice processes play significant roles in the Southern Ocean's climate variability and bottom water formation (e.g., Jacobs and Comiso, 1989; Venegas and Drinkwater, 2001). Although CFSR and ECCO2 both contained sea-ice models, they portrayed deep water masses as being warmer than what was provided in the observations, and CFSR also showed fresher waters at the deep layer (Figs. 2-9). Neither of these two reanalysis systems was able to properly reproduce the WSBW layer $\left(\gamma^{\mathrm{n}} \geq 28.40 \mathrm{~kg} \mathrm{~m}^{-3}\right)$. However, ECCO2 represented the spatial variability and water mass distribution well with respect to the in situ data (Fig. 10). Conversely, the SODA and ECMWF reanalyses represented absolute values of $\theta, S$ and $\gamma^{\mathrm{n}}$ of the deep waters that were close to observations despite the absence of a suitably coupled sea-ice model. This result highlights the fact that surface data assimilation in those products are responding satisfactorily to represent the processes and exchanges at the air-sea interface.

None of the reanalyses represented the downslope flow of dense water in the western slope of section WOCE SR4 (Figs. 5, 7, 9). Those limitations are expected for $z$ level models (Winton et al., 1998), which could lead to excessive diapycnal mixing and poor representation of downslope flows (Willebrand et al., 2001). A simple way to improve the representation of denser varieties of AABW is to use certain procedures to directly inject dense water from the continental shelf to the deep ocean (e.g., Briegleb et al., 2010). Recently, Heuzé et al. (2013) showed that the process of AABW formation was not represented accurately in climate models, leading to extensive areas of deep ocean convection. Kerr et al. (2012a) investigated a high-resolution $\left(1 / 12^{\circ}\right)$ simulation of the OCCAM model and noted that despite the absence of a dense shelf break and slope plume in the model, the presence of deep ocean convection could explain the relatively good $\mathrm{AABW}$ export rates to the global ocean from 

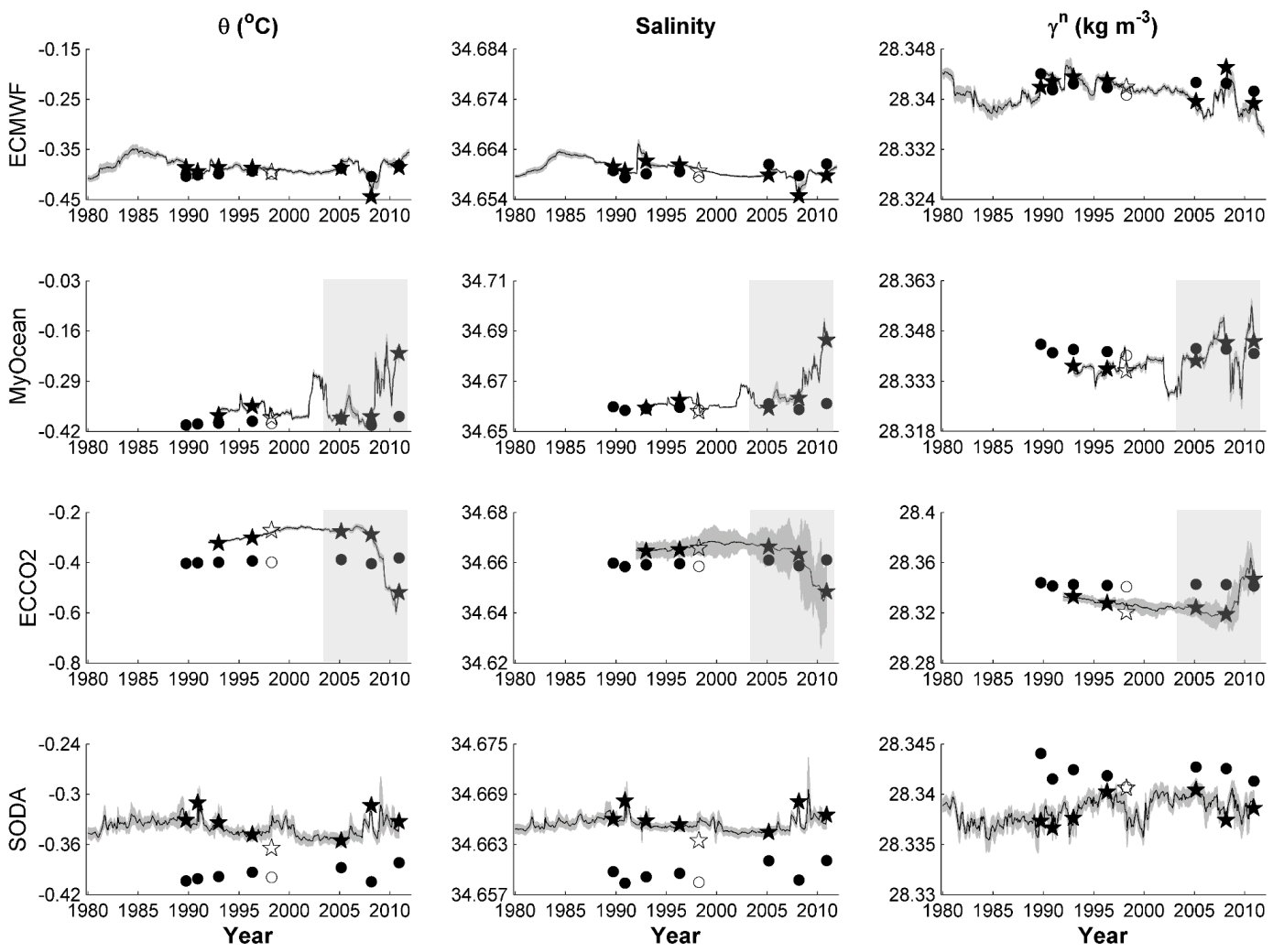

Figure 14. Same as in Fig. 12, but for WSDW.

the Weddell Sea. Heuzé et al. (2013) suggested that a superparameterization scheme, perhaps based on a high-resolution isopycnal model, might improve the downslope-flow representation. In addition, the use of a low-vertical-resolution model for deep ocean layers is not effective in representing water masses such as WSBW, which is less than $1 \mathrm{~km}$ thick (e.g., Fahrbach et al., 2001; Kerr et al., 2009a). Thus, increasing the vertical resolution of the deep and bottom layers in ocean models, which is frequently performed for the surface ocean, could be further considered to more consistently represent the deep ocean structure and make future ocean models more accurate.

Adding ice shelves in a coupled sea ice-ocean model improves the simulation of the sea-ice cover and alters the hydrography in the Weddell Sea with global effects, as shown by Hellmer (2004) and Wang and Beckmann (2007). Kerr et al. (2009b) and Renner et al. (2009) also noted the need for adequate sea-ice models and the inclusion of ice-shelf processes to improve simulations of global ocean circulation models. More recently, Meccia et al. (2013), using a regional ocean model, showed that the representation of Ice Shelf Water was improved in their experiment that included ice-shelf thermodynamic parameterization in the Weddell Sea. None of the reanalyses discussed here included the ice shelves in their simulations, even though such shelves are key elements in the formation of Ice Shelf Water - water masses that are directly involved in the formation of WSBW (Foldvik et al., 1985). MyOcean simulations included the effects of the Antarctica ice sheet melt in its oceanic model, and this inclusion may have improved the representation of its surface salinity absolute values (Figs. 6, 7). Ice-shelf effects on the ocean structure could be inserted in ocean reanalysis products if observations near those areas became available. The inclusion of ice shelves in models is a factor that must be strongly considered for the optimization of deep-ocean representation in future reanalysis results, but more observations under permanent ice shelves would also most likely result in better ocean reanalysis outputs in the Weddell Sea.

Ocean reanalysis products are powerful tools for climate studies because of their generally high-temporal resolution. Thus, the horizontal and vertical spatial-average representations and their temporal variability should be assessed. Over the last decade, several studies have highlighted the variability and trends in the hydrographic properties of the Weddell Sea. The most prominent trend is the WDW warming from the 1970s to the 2000s (Robertson et al., 2002; Smedsrud, 2005; Fahrbach et al., 2004, 2011). Considering the products investigated here, only the SODA reanalysis showed a statistically significant WDW warming trend $\left(+0.0041^{\circ} \mathrm{C} \mathrm{yr}^{-1}\right.$; Table 4$)$ in the WOCE SR4 section during the 1980-2010 period. This trend found by the SODA product was less than that observed at the WDW inflow in the 

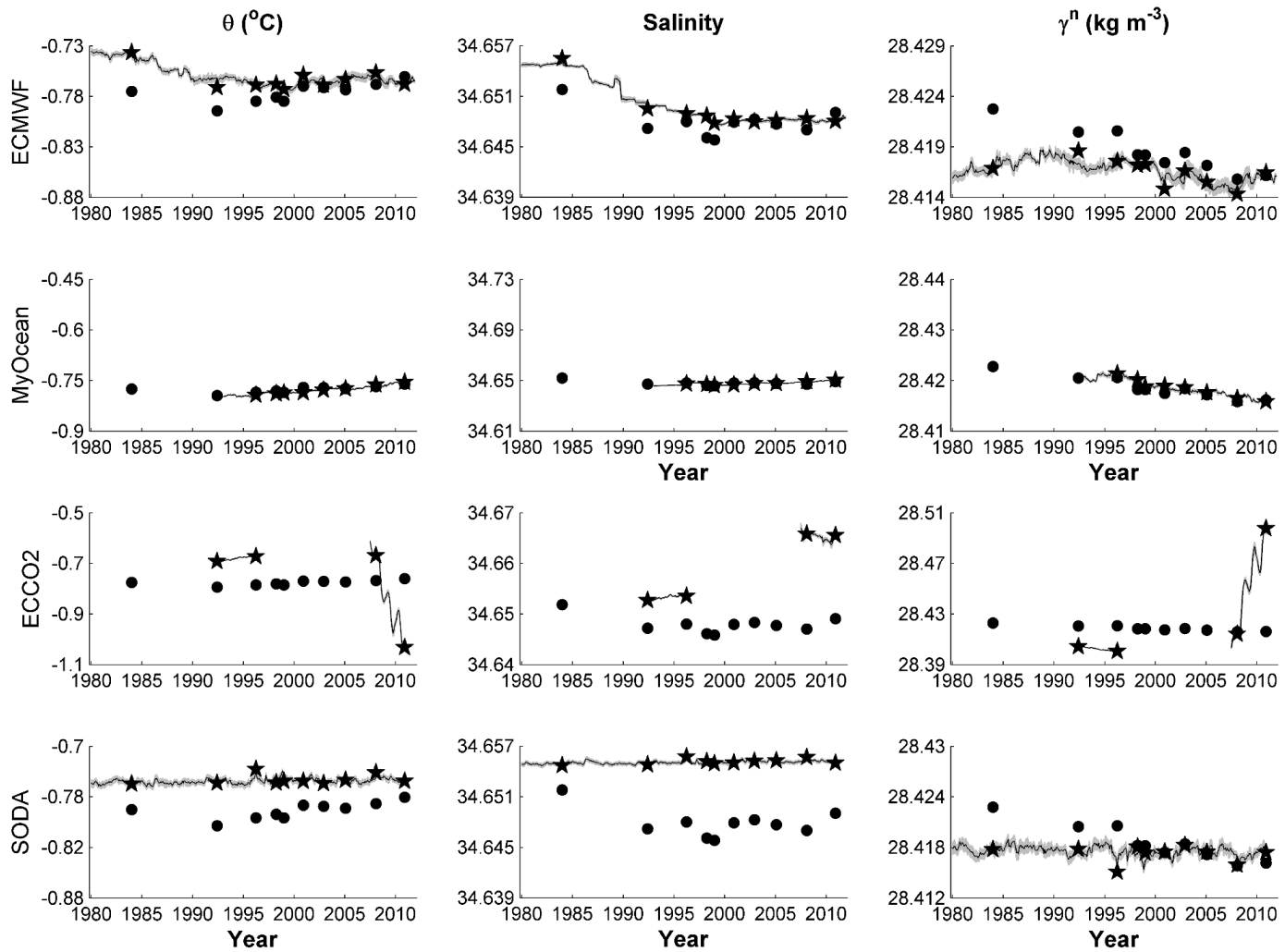

Figure 15. Same as in Fig. 11, but for WSBW.

Weddell Sea from 1971 to $2000\left(+0.012{ }^{\circ} \mathrm{C} \mathrm{yr}^{-1}\right.$; Robertson et al., 2002), which could be associated with the evaluation of the entire section here. In contrast, the ECMWF, MyOcean and ECCO2 products showed statistically significant cooling trends (Table 4) in both sections for the periods 1980-2011, 1993-2004 and 1992-2004, respectively. Following the cooling shown in ECMWF, MyOcean, and $\mathrm{ECCO} 2$, the products showed a freshening trend, whereas in SODA, $S$ increased with time (Table 4). According to observed data, WDW freshened during the 1971-2000 period (see, for instance, Fig. 9 from Robertson et al., 2002). However, sparse temporal data showed an increase in salinity between the 1980s and the 2000s (Fahrbach et al., 2004, 2011). In association with the $\theta$ trends, $\gamma^{\mathrm{n}}$ showed an increasing trend in ECMWF and MyOcean (and a decreasing trend in SODA). Robertson et al. (2002) clearly showed that WDW density decreased during the period 1971-2000.

Fahrbach et al. (2011) reported warming and increasing salinity trends for the WSDW layer between the 1980s and 2000s in section WOCE A12. In this context, all reanalysis products that had statistically significant trends showed cooling and freshening trends for this section, which were associated with an increase in density (Table 4). This discrepancy may have been caused by the different criteria used to define the AABW varieties. Robertson et al. (2002) also found a warming trend from the 1970s to 1990s in the WOCE SR4 section, although their results were not statistically significant given the interannual variability of their data. In this section, a warming trend $\left(+0.0049^{\circ} \mathrm{C} \mathrm{yr}^{-1}\right)$ was reproduced by ECCO2 (1992-2004) followed by an increase in salinity $\left(+0.0003 \mathrm{yr}^{-1}\right)$. The MyOcean reanalysis (1993-2004) also showed an increase in $\theta$ and $S$, but none of the properties considered were statistically significant (Table 4). All reanalyses examined showed a $\gamma^{\mathrm{n}}$ decreasing trend for WOCE SR4 (except for the SODA product; Table 4). AABW observations showed a warming trend for the global AABW exported from the Southern Ocean and a reduction in its volume (e.g., Purkey and Johnson, 2010, 2012; Azaneu et al., 2013). The latter may be a consequence of the downward trend in AABW density, although no sign of freshening has been found in the inner Weddell Sea (Azaneu et al., 2013). Recently, Jullion et al. (2013) reported a significant freshening of AABW of -0.004 decade $^{-1}$ in the Drake Passage, with no significant decrease in its thickness. In section WOCE A12, the reanalyses showed a freshening trend in WSDW of the same order as that found by Jullion et al. (2013) and Azaneu et al. (2013) for AABW. In section WOCE SR4, only ECMWF showed a freshening trend that corresponded with the one found by Azaneu et al. (2013, Table 4).

Throughout the Weddell Sea, bottom waters have been warming with no clear change in salinity (e.g., Robertson et al., 2002; Fahrbach et al., 2004, 2011; Purkey and Johnson, 

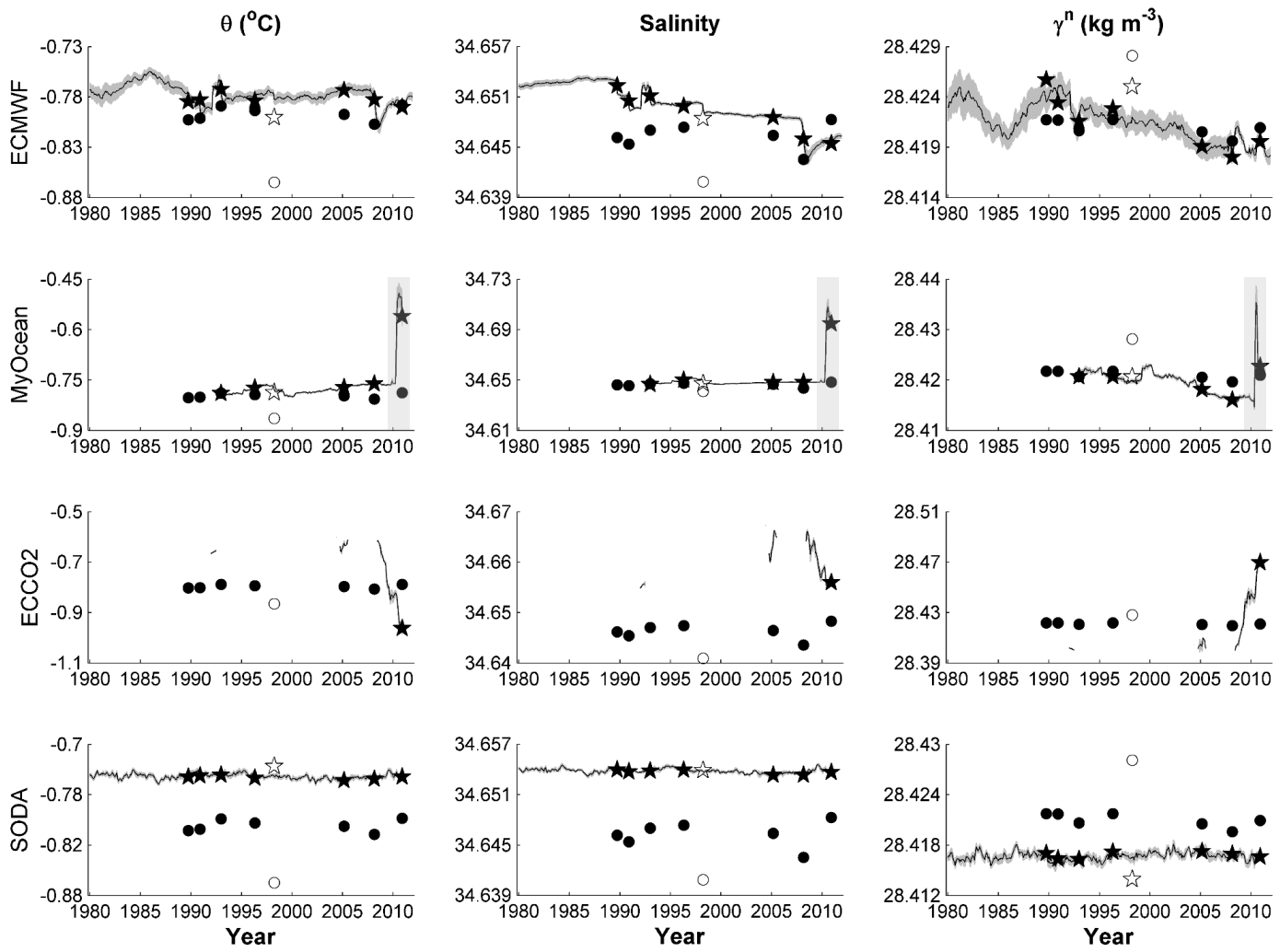

Figure 16. Same as in Fig. 12, but for WSBW.

2010; Azaneu et al., 2013). Considering all statistically significant results of the ocean reanalysis time series, the density of WSBW is declining, but the causes are not clear because both cooling/freshening and warming/increasing salinity were reproduced (Table 4). The ocean reanalyses that showed a warming trend (MyOcean and SODA) also presented an increase in salinity, while ECMWF showed cooling and freshening trends (Table 4). A freshening trend of the WSBW would be expected as a result of shelf water freshening (e.g., Hellmer et al., 2011; Azaneu et al., 2013) because this bottom water results from shelf water mixing. However, clear salinity changes have not yet been observed in the deep layers of the Weddell Sea (Azaneu et al., 2013); the causes are not yet clearly identified but could be the result of the opposing effects of source waters and dynamic processes masking signal identification.

In general, it appears that all of the reanalysis products require considerable development to improve their representation of the Weddell Sea water masses, particularly in their representation of dense-water production and overflows. The choice of the reanalysis product that best reproduces the main regional oceanographic patterns depends upon one's particular interest. For example, if the primary interest is in describing prominent oceanographic features, e.g., water mass distribution and thermohaline values, MyOcean produces results closest to the observational data; thus, MyOcean is considered the best product for this purpose. If trends and temporal variability in the water masses are the major motivations, the choice of reanalysis product is dependent on the water mass evaluated. For WDW, SODA captured the warming, the salinity increase and the density decrease patterns that were found in the observations. For WSDW, the ECCO2 results were closer to the observational estimates, reproducing the freshening trends in WOCE SR4 and the warming in WOCE SR4 and WOCE A12. Finally, for WSBW, MyOcean and SODA were able to capture the warming pattern recorded in the data set, although the simulated salinity increase in WOCE A12 and decrease in WOCE SR4 are not clear in the real ocean. Caution is advised regarding the anomalous periods that were seen in most of the reanalyses that were assessed.

Overall, our results suggest that the MyOcean and SODA products are valuable tools for studying the states of deep layers in the Weddell Sea because these tools closely reproduce the hydrographic absolute values of the observational data and capture the main regional features. More effort is needed to address surface layers because several complex processes acting on the ocean surface - e.g., atmosphereocean-cryosphere interactions - may not be correctly reproduced, causing large differences in absolute values. A good representation of the surface layer is also vital for the representation of the deep layers because deep water 
masses are dependent on the thermohaline characteristics of surface water masses (Foster and Carmack, 1976) that result from these atmosphere-ocean-cryosphere interactions (Whitworth et al., 1998). The variability and trends represented by ocean reanalyses may still have some biases because the Southern Ocean suffers from a lack of in situ data and is biased by summer observations. A better representation of ocean features and hydrographic properties by ocean reanalysis will be useful for long-term studies in polar regions to better understand the connections between ocean variability and possible implications for the global climate.

Acknowledgements. We thank the research groups involved in each ocean reanalysis system for making their simulations freely available. ECMWF ORAS4 was provided by ECMWF (http://www.ecmwf.int/); CFSR was provided by the Environmental Modeling Center, National Centers for Environmental Prediction, National Weather Service, NOAA, US Department of Commerce from its website http://rda.ucar.edu/datasets/ds093.2; MyOcean UR025.4 was provided by MyOcean Products from its website http://www.myocean.eu/; ECCO2 was provided by the ECCO2/MAP/NASA (http://ecco2.jpl.nasa.gov/); and SODA was provided from the SODA program (http://www.atmos.umd.edu/ ocean/). T. S. Dotto and M. Azaneu acknowledge financial support from the CAPES Foundation. This study is a contribution to the activities of the Brazilian High Latitudes Oceanography Group (GOAL; www.goal.furg.br) and the Brazilian National Institute of Science and Technology of Cryosphere (INCT-CRIOSFERA; 573720/2008-8). GOAL has been funded by the Brazilian Antarctic Program (PROANTAR), the Brazilian Ministry of the Environment (MMA), the Brazilian Ministry of Science, Technology and Innovation (MCTI), the Council for Research and Scientific Development of Brazil (CNPq grants no. 520189/2006-0; 556848/2009-8), and grant 2013/02111-4 from the Sao Paulo Research Foundation (FAPESP). We acknowledge two anonymous reviewers for their constructive comments, which greatly improved the manuscript. This work is dedicated to the memory of Eberhard Fahrbach, who died on 21 April 2013. Without his vision and efforts, this most valuable data set of the Weddell Sea covering more than two decades would not exist.

Edited by: A. Schiller

\section{References}

Azaneu, M., Kerr, R., Mata, M. M., and Garcia, C. A. E.: Trends in the deep Southern Ocean (1958-2010): Implications for Antarctic bottom water properties and volume export, J. Geophys. Res., 118, 4213-4227, doi:10.1002/jgrc.20303, 2013.

Azaneu, M., Kerr, R., and Mata, M. M.: Assessment of the ECCO2 reanalysis on the representation of Antarctic Bottom Water properties, Ocean Sci. Discuss., 11, 1023-1091, doi:10.5194/osd-111023-2014, 2014.

Balmaseda, M. A., Mogensen, K., and Weaver, A. T.: Evaluation of the ECMWF ocean reanalysis system ORAS4, Q. J. Roy. Meteorol. Soc., 139, 1132-1161, doi:10.1002/qj.2063, 2013.
Briegleb, B., Danabasoglu, G., and Large, W.: An overflow parameterization for the ocean component of the Community Climate System Model, Tech. Note NCAR/TN-481+ STR, 84 pp., 2010.

Bromwich, D. H., Nicolas, J. P., and Monaghan, A. J.: An assessment of precipitation changes over Antarctica and the Southern Ocean since 1989 in contemporary global reanalyses, J. Climate, 24, 4189-4209, doi:10.1175/2011JCLI4074.1, 2011.

Carmack, E. C. and Foster, T. D.: On the flow of water out of the Weddell Sea, Deep Sea Res., 22, 711-724, doi:10.1016/00117471(75)90077-7, 1975.

Carton, J. A. and Giese, B. S.: A Reanalysis of Ocean Climate Using Simple Ocean Data Assimilation (SODA), Mon. Weather Rev., 136, 2999-3017, doi:10.1175/2007MWR1978.1, 2008.

Carton, J. A. and Santorelli, A.: Global decadal upper-ocean heat content as viewed in nine analyses, J. Climate, 21, 6015-6035, doi:10.1175/2008JCLI2489.1, 2008.

Compo, G. P., Whitaker, J. S., Sardeshmukh, P. D., Matsui, N., Allan, R. J., Yin, X., Gleason, B. E., Vose, R. S., Rutledge, G., Bessemoulin, P., Brönnimann, S., Brunet, M., Crouthamel, R. I., Grant, A. N., Groisman, P. Y., Jones, P. D., Kruk, M. C., Kruger, A. C., Marshall, G. J., Maugeri, M., Mok, H. Y., Nordli, Ø., Ross, T. F., Trigo, R. M., Wang, X. L., Woodruff, S. D., and Worley, S. J.: The twentieth century reanalysis project, Q. J. Roy. Meteorol. Soc., 137, 1-28, doi:10.1002/qj.776, 2011.

Dee, D. P.: Bias and data assimilation, Q. J. Roy. Meteorol. Soc., 131, 3323-3343, doi:10.1256/qj.05.137, 2005.

Dee, D. P., Uppala, S. M., Simmons, A. J., Berrisford, P., Poli, P., Kobayashi, S., Andrae, U., Balmaseda, M. A., Balsamo, G., Bauer, P., Bechtold, P., Beljaars, A. C. M., van de Berg, L., Bidlot, J., Bormann, N., Delsol, C., Dragani, R., Fuentes, M., Geer, A. J., Haimberger, L., Healy, S. B., Hersbach, H., Hólm, E. V., Isaksen, L., Kållberg, P., Köhler, M., Matricardi, M., McNally, A. P., Monge-Sanz, B. M., Morcrette, J.-J., Park, B.-K., Peubey, C., de Rosnay, P., Tavolato, C., Thépaut, J.-N., and Vitart, F.: The ERA Interim reanalysis: Configuration and performance of the data assimilation system, Q. J. Roy. Meteorol. Soc., 137, 553597, doi:10.1002/qj.828, 2011.

Fahrbach, E. and De Baar, H.: The Expedition of the Research Vessel Polarstern to the Antarctic in 2008 (ANT-XXIV/3). Berichtezur Polar- und Meeresforschung, Vol. 606, AlfredWegener-Institut, Bremerhaven, 228 pp., 2010.

Fahrbach, E., Rohardt, G., Scheele, N., Schröder, M., Strass, V., and Wisotzki, A.: Formation and discharge of deep and bottom water in the northwestern Weddell Sea, J. Marine Res., 53, 515-538, doi:10.1357/0022240953213089, 1995.

Fahrbach, E., Harms, S., Rohardt, G., Schröder, M., and Woodgate, R. A.: Flow of bottom water in the northwestern Weddell Sea, J. Geophys. Res., 106, 2761-2778, doi:10.1029/2000JC900142, 2001.

Fahrbach, E., Hoppema, M., Rohardt, G., Schröder, M., and Wisotzki, A.: Decadal-scale variations of water mass properties in the deep Weddell Sea, Ocean Dynam., 54, 77-91, doi:10.1007/s10236-003-0082-3, 2004.

Fahrbach, E., Rohardt, G., and Sieger, R.: 25 Years of Polarstern hydrography (1982-2007), WDC-MARE Reports 5, AlfredWegener-Institut, Bremerhaven, 94 pp., 2007.

Fahrbach, E., Hoppema, M., Rohardt, G., Boebel, O., Klatt, O., and Wisotzki, A.: Warming of deep and abyssal water masses along the Greenwich meridian on decadal time scales: The Wed- 
dell gyre as a heat buffer, Deep Sea Res. Pt. II, 58, 2509-2523, doi:10.1016/j.dsr2.2011.06.007, 2011.

Ferry, N., Barnier, B., Garric, G., Haines, K., Masina, S., Parent, L., Storto, A., Valdivieso, M., Guinehut, S., and Mulet, S.: Nemo: The modelling engine of global ocean reanalysis, Mercator Ocean Quarterly Newsletter, 46, 46-59, 2012.

Fichefet, T. and Morales-Maqueda, M. A.: Sensitivity of a global sea ice model to the treatment of ice thermodynamics and dynamics, J. Geophys. Res., 102, 12609-12646, doi:10.1029/97JC00480, 1997.

Foldvik, A., Gammelsrød, T., and Tørrensen, T.: Circulations and Water Masses on the Southern Weddell Sea Shelf, Antarctic Research Series, 43, 5-20, 1985.

Foster, T. and Carmack, E.: Temperature and salinity structure in the Weddell Sea, J. Phys. Oceanogr., 6, 36-44, doi:10.1175/15200485(1976)006<0036:TASSIT>2.0.CO;2, 1976.

Franco, B., Mata, M. M., Piola, A., and Garcia, C. A. E.: Northwestern Weddell Sea deep outflow into the Scotia Sea during the austral summers of 2000 and 2001 estimated by inverse methods, Deep Sea Res. Pt. I, 54, 1815-1840, doi:10.1016/j.dsr.2007.06.003, 2007.

Giese, B. S. and Ray, S.: El Niño variability in simple ocean data assimilation (SODA), 1871-2008, J. Geophys. Res., 116, C02024, doi:10.1029/2010JC006695, 2011.

Gouretski, V. and Danilov, A.: Weddell Gyre: structure of the eastern boundary, Deep Sea Res. Pt. I, 40, 561-582, doi:10.1016/0967-0637(93)90146-T, 1993.

Griffies, S. M., Harrison, M. J., Pacanowski, R. C., and Rosati, A.: A Technical Guide to MOM4, GFDL Ocean Group Technical Report No. 5, NOAA/Geophysical Fluid Dynamics Laboratory, available at: www.gfdl.noaa.gov (last access: 12 February 2014), 2008.

Hellmer, H. H.: Impact of Antarctic ice shelf basal melting on sea ice and deep ocean properties, Geophys. Res. Lett., 31, L10307, doi:10.1029/2004GL019506, 2004.

Hellmer, H. H., Schodlok, M. P., Wenzel, M., and Schröter, J. G.: On the influence of adequate Weddell Sea characteristics in a large-scale global ocean circulation model, Ocean Dynam., 55, 88-99, doi:10.1007/s10236-005-0112-4, 2005.

Hellmer, H. H., Huhn, O., Gomis, D., and Timmermann, R.: On the freshening of the northwestern Weddell Sea continental shelf, Ocean Sci., 7, 305-316, doi:10.5194/os-7-305-2011, 2011.

Heuzé, C., Heywood, K. J., Stevens, D. P., and Ridley, J. K.: Southern Ocean bottom water characteristics in CMIP5 models, Geophys. Res. Lett., 40, 1-6, doi:10.1002/grl.50287, 2013.

Holland, D. M.: Transient sea-ice polynya forced by oceanic flow variability, Progr. Oceanogr., 48, 403-460, doi:10.1016/S00796611(01)00010-6, 2001.

Huhn, O., Hellmer, H. H., Rhein, M., Rodehacke, C. B., Roether, W., Schodlok, M. P., and Schroder, M.: Evidence of deep and bottom water formation in the western Weddell Sea, Deep Sea Res. Pt. II, 55, 1098-1116, doi:10.1016/j.dsr2.2007.12.015, 2008.

Huhn, O., Hellmer, H. H., Rhein, M., Rodehacke, C. B., Roether, W., Schodlok, M. P., and Schröder, M.: Evidence of deep and bottom water formation in the western Weddell Sea, Deep Sea Res. Pt. II, 55, 1098-1116, doi:10.1016/j.dsr2.2007.12.015, 2008.

Jackett, D. R. and McDougall, T. J.: A neutral density variable for the world's oceans, J. Phys. Oceanogr., 27, 237-263,
doi:10.1175/1520-0485(1997)027<0237:ANDVFT>2.0.CO;2, 1997.

Jacobs, S. S. and Comiso, J. C.: Sea ice and oceanic processes on the Ross Sea continental shelf, J. Geophys. Res., 94, 18195, doi:10.1029/JC094iC12p18195, 1989.

Jullion, L., Naveira Garabato, A. C., Meredith, M. P., Holland, P. R., Courtois, P., and King, B. A.: Decadal freshening of the Antarctic Bottom Water exported from the Weddell Sea, J. Climate, 26, 8111-8125, doi:10.1175/JCLI-D-12-00765.1, 2013.

Kerr, R., Mata, M. M., and Garcia, C. A. E.: On the temporal variability of the Weddell Sea Deep Water masses, Antarctic Science, 21, 383-400, doi:10.1017/S0954102009001990, 2009a.

Kerr, R., Wainer, I., and Mata, M. M.: Representation of the Weddell Sea deep water masses in the ocean component of the NCARCCSM model, Antarctic Sci., 21, 301-312, 2009 b.

Kerr, R., Heywood, K. J., Mata, M. M., and Garcia, C. A. E.: On the outflow of dense water from the Weddell and Ross Seas in OCCAM model, Ocean Sci., 8, 369-388, doi:10.5194/os-8-3692012, 2012a.

Kerr, R., Wainer, I., Mata, M. M., and Garcia, C. A. E.: Quantifying Antarctic deep waters in SODA reanalysis product, Pesquisa Antártica Brasileira, 5, 47-59, 2012b.

Klatt, O., Fahrbach, E., Hoppema, M., and Rohardt, G.: The transport of the Weddell Gyre across the Prime Meridian, Deep Sea Res. Pt. II, 52, 513-528, doi:10.1016/j.dsr2.2004.12.015, 2005.

Large, W. G. and Yeager, S. G.: The global climatology of an interannually varying air-sea flux data set, Clim. Dynam., 33, 341364, doi:10.1007/s00382-008-0441-3, 2009.

Lumpkin, R. and Speer, K.: Global Ocean Meridional Overturning, J. Phys. Oceanogr., 37, 2550-2562, doi:10.1175/JPO3130.1, 2007.

Madec, G.: NEMO ocean engine, Note du Pôle de modélisation de l'Institut Pierre-Simon Laplace, 27, 217 pp., 2008.

Marshall, J., Adcroft, A., Hill, C., Perelman, L., and Heisey, C.: A finite-volume, ncompressible Navier Stokes model for studies of the ocean on parallel computers, J. Geophys. Res., 102, 57535766, doi:10.1029/96JC02775, 1997.

Meccia, V., Wainer, I., Tonelli, M., and Curchitser, E.: Coupling a thermodynamically active ice shelf to a regional simulation of the Weddell Sea, Geosci. Model Dev., 6, 1209-1219, doi:10.5194/gmd-6-1209-2013, 2013.

Menemenlis, D., Fukumori, I., and Lee, T.: Using Green's functions to calibrate an ocean general circulation model, Mon. Weather Rev., 133, 1224-1240, doi:10.1175/MWR2912.1, 2005.

Menemenlis, D., Campin, J.M., Heimbach, P., Hill, C., Lee, T., Nguyen, A., Schodlok, M., and Zhang, H.: ECCO2: High Resolution Global Ocean and Sea Ice Data Synthesis, Mercator Ocean Quarterly Newsletter, 31, 13-21, 2008.

Mogensen, K., Alonso, M., and Weaver, A.: The NEMOVAR ocean data assimilation system as implemented in the ECMWF ocean analysis for System 4, Technical Memorandum, 668, 59 pp., 2012.

Naveira Garabato, A. C., McDonagh, E. L., Stevens, D. P., Heywood, K. J., and Sanders, R. J.: On the export of Antarctic Bottom Water from the Weddell Sea, Deep Sea Res. Pt. II, 49, 47154742, doi:10.1016/S0967-0645(02)00156-X, 2002.

Nicholls, K. W., Østerhus, S., Makinson, K., Gammelsrød, T., and Fahrbach, E.: Ice-Ocean processes ocer the continental shelf of 
the southern Weddell Sea, Antarctica: A review, Rev. Geophys., 47, RG3003, doi:10.1029/2007RG000250, 2009.

Ohshima, K. I., Fukamachi, Y., Williams, G. D., Nihashi, S., Roquet, F., Kitade, Y., Tamura, T., Hirano, D., HerraizBorreguero, L., Field, I., Hindell, M., Aoki, S., and Wakatsuchi, M.: Antarctic Bottom Water production by intense sea-ice formation in the Cape Darnley polynya, Nat. Geosci., 6, 235-240, doi:10.1038/ngeo1738, 2013.

Onogi, K., Tsutsui, J., Koide, H., Sakamoto, M., Kobayashi, S., Hatsushika, H., Matsumoto, T., Yamazaki, N., Kamahori, H., Takahashi, K., Kodokura, S., Wada, K., Kato, K., Oyama, R., Ose, T., Mannoji, N., and Taira, R.: The JRA-25 reanalysis, J. Meteorol. Soc. Jpn., 85, 369-432, 2007.

Orsi, A. H., Nowlin Jr., W. D., and Whitworth III, T.: On the circulation and stratification of the Weddell Gyre, Deep Sea Res. Pt. I, 40, 169-203, doi:10.1016/0967-0637(93)90060-G, 1993.

Orsi, A. H., Whitworth III, T., and Nowlin Jr., W. D.: On the meridional extent and fronts of the Antarctic Circumpolar Current, Deep Sea Res. I, 42, 641-673, doi:10.1016/09670637(95)00021-W, 1995.

Orsi, A. H., Johnson, G. C., and Bullister, J. L.: Circulation, mixing, and production of Antarctic Bottom Water, Progr. Oceanogr., 43, 55-109, doi:10.1016/S0079-6611(99)00004-X, 1999.

Purkey, S. G. and Johnson, G. C.: Warming of Global Abyssal and Deep Southern Ocean Waters between the 1990s and 2000s: Contributions to Global Heat and Sea Level Rise Budgets, J. Climate, 23, 6336-6351, doi:10.1175/2010JCLI3682.1, 2010.

Purkey, S. G. and Johnson, G. C.: Global Contraction of Antarctic Bottom Water between the 1980s and 2000s, J. Climate, 25, 5830-5844, doi:10.1175/JCLI-D-11-00612.1, 2012.

Rayner, N. A., Parker, D. E., Horton, E. B., Folland, C. K., Alexander, L. V., Rowell, D. P., Kent, E. C., and Kaplan, A.: Global analyses of sea surface temperature, sea ice, and night marine air temperature since the late nineteenth century, J. Geophys. Res., 108, 4407, doi:10.1029/2002JD002670, 2003.

Renner, A. H. H., Heywood, K. J., and Thorpe, S. E.: Validation of three global ocean models in the Weddell Sea, Ocean Modell., 30, 1-15, doi:10.1016/j.ocemod.2009.05.007, 2009.

Reynolds, R. W., Rayner, N. A., Smith, T. M., Stokes, D. C., and Wang, W.: An improved in situ and satellite SST analysis for climate, J. Climate, 15, 1609-1625, doi:10.1175/15200442(2002)015<1609:AIISAS>2.0.CO;2, 2002.

Reynolds, R. W., Smith, T. M., Liu, C., Chelton, D. B., Casey, K. S., and Schlax, M. G.: Daily high-resolution-blended analyses for sea surface temperature, J. Climate, 20, 5473-5496, 2007.

Robertson, R., Visbeck, M., Gordon, A. L., and Fahrbach, E.: Long-term temperature trends in the deep waters of the Weddell Sea, Deep Sea Res. Pt. II, 49, 4791-4806, doi:10.1016/S09670645(02)00159-5, 2002.

Rohardt, G., Fahrbach, E., and Wisotzki, A.: Physical oceanography during POLARSTERN cruise ANT-XXVII/2, Alfred Wegener Institute, Helmholtz Center for Polar and Marine Research, Bremerhaven, doi:10.1594/PANGAEA.772244, 2011.

Saha, S., Moorthi, S., Pan, H.-L., Wu, Z., Wang, J., Nadiga, S., Tripp, P., Kistler, R., Woollen, J., Behringer, D., Liu, H., Stokes, D., Grumbine, R., Gayno, G., Wang, J., Hou, Y.-T., Chuang, H.Y., Juang, H.-M. H., Sela, J., Iredell, M., Treadon, R., Kleist, D., Van Delst, P., Keyser, D., Derber, J., Ek, M., Meng, J., Wei, H., Yang, R., Lord, S., Van Den Dool, H., Kumar, A., Wang,
W., Long, C., Chelliah, M., Xue, Y., Huang, B., Schemm, J.-K., Ebisuzaki, W., Lin, R., Xie, P., Chen, M., Zhou, S., Higgins, W., Zou, C.-Z., Liu, Q., Chen, Y., Han, Y., Cucurull, L., Reynolds, R. W., Rutledge, G., and Goldberg, M.: The NCEP climate forecast system reanalysis, Bull. Am. Meteorol. Soc., 91, 1015-1057, doi:10.1175/2010BAMS3001.1, 2010.

Schröder, M. and Fahrbach, E.: On the structure and the transport of the eastern Weddell Gyre, Deep-Sea Res. Pt. II, 46, 501-527, doi:10.1016/S0967-0645(98)00112-X, 1999.

Smedsrud, L. H.: Warming of the deep water in the Weddell Sea along the Greenwich meridian: 1977-2001, Deep Sea Res. Pt. I, 52, 241-258, doi:10.1016/j.dsr.2004.10.004, 2005.

Smith, R., Dukowicz, J., and Malone, R.: Parallel ocean general circulation modeling, Physica D: Nonlinear Phenomena, 60, 38 61, doi:10.1016/0167-2789(92)90225-C, 1992.

Stark, J. D., Donlon, C. J., Martin, M. J., and McCulloch, M. E.: OSTIA: An operational, high resolution, real time, global sea surface temperature analysis system, In: Oceans'07 IEEE Aberdeen, conference proceedings. Marine challenges: coastline to deep sea. Aberdeen, Scotland, IEEE., 1-4, 2007.

Storkey, D., Blockley, E. W., Furner, R., Guiavarc'h, C., Lea, D., Martin, M. J., Barciela, R. M., Hines, A., Hyder, P., and Siddorn, J. R.: Forecasting the ocean state using NEMO: The new FOAM system, J. Operational Oceanogr., 3, 3-15, 2010.

Talley, L. D.: Closure of the global overturning circulation through the Indian, Pacific, and Southern Oceans: Schematics and transports, Oceanography, 26, 80-97, doi:10.5670/oceanog.2013.07, 2013.

Taylor, K. E.: Summarizing multiple aspects of model performance in a single diagram, J. Geophys. Res., 106, 7183-7192, doi:10.1029/2000JD900719, 2001.

Uppala, S. M., KÅllberg, P. W., Simmons, A. J., Andrae, U., Bechtold, V. D. C., Fiorino, M., Gibson, J. K., Haseler, J., Hernandez, A., Kelly, G. A., Li, X., Onogi, K., Saarinen, S., Sokka, N., Allan, R. P., Andersson, E., Arpe, K., Balmaseda, M. A., Beljaars, A. C. M., Berg, L. V. D., Bidlot, J., Bormann, N., Caires, S., Chevallier, F., Dethof, A., Dragosavac, M., Fisher, M., Fuentes, M., Hagemann, S., Hólm, E., Hoskins, B. J., Isaksen, L., Janssen, P. A. E. M., Jenne, R., Mcnally, A. P., Mahfouf, J.-F., Morcrette, J.-J., Rayner, N. A., Saunders, R. W., Simon, P., Sterl, A., Trenberth, K. E., Untch, A., Vasiljevic, D., Viterbo, P., and Woollen, J.: The ERA-40 re-analysis, Q. J. Roy. Meteorol. Soc., 131, 2961-3012, doi:10.1256/qj.04.176, 2005.

van Sebille, E., Spence, P., Mazloff, M. R., England, M. H., Rintoul, S. R., and Saenko, O. A.: Abyssal connections of Antarctic Bottom Water in a Southern Ocean State Estimate, Geophys. Res. Lett., 40, 2177-2182, doi:10.1002/grl.50483, 2013.

Venegas, S. A. and Drinkwater, M. R.: Sea ice, atmosphere and upper ocean variability in the Weddell Sea, Antarctica, J. Geophys. Res., 106, 16747-16766, doi:10.1029/2000JC000594, 2001.

Wang, C. and Beckmann, A.: Investigation of the impact of Antarctic ice-shelf melting in a global ice-ocean model (ORCA2-LIM), Ann. Glaciol., 46, 78-82, doi:10.3189/172756407782871602, 2007.

Whitworth III, T. and Nowlin Jr., W. D.: Water masses and currents of the Southern Ocean at the Greenwich meridian, J. Geophys. Res., 92, 6462-6476, doi:10.1029/JC092iC06p06462, 1987.

Whitworth III, T., Orsi, A. H., Kim, S. J., Nowlin Jr., W. D., and Locarnini R. A.: Water masses and mixing near the Antarctic 
slope front, in: Ocean, Ice, and Atmosphere: Interactions at the Antarctic Continental Margin, Antarct. Res. Ser., 75, edited by: Jacobs, S. S. and Weiss, R. F., 26 pp., AGU, Washington, DC, 1998.

Willebrand, J., Barnier, B., Böning, C., Dieterich, C., Killworth, P. D., Le Provost, C., Jia, Y., Molines, J.-M., and New, A. L.: Circulation characteristics in three eddy-permitting models of the North Atlantic, Progr. Oceanogr., 48, 123-161, doi:10.1016/S0079-6611(01)00003-9, 2001.

Winton, M., Hallberg, R., and Gnanadesikan, A.: Simulation of Density-Driven Frictional Downslope Flow in ZCoordinate Ocean Models, J. Phys. Oceanogr., 28, 2163-2174, doi:10.1175/1520-0485(1998)028<2163:SODDFD>2.0.CO;2, 1998.
Woodruff, S. D., Worley, S. J., Lubker, S. J., Ji, Z., Freeman, J. E., Berry, D. I., Brohan, P., Kent, E. C., Reynolds, R. W., Smith, S. R., and Wilkinson, C.: ICOADS Release 2.5: Extensions and enhancements to the surface marine meteorological archive, Int. J. Climatol., 31, 951-967, doi:10.1002/joc.2103, 2011.

Worley, S. J., Woodruff, S. D., Reynolds, R. W., Lubker, S. J., and Lott, N.: ICOADS release 2.1 data and products, International J. Climatol., 25, 823-842, doi:10.1002/joc.1166, 2005.

Xue, Y., Huang, B., Hu, Z.-Z., Kumar, A. A., Wen, C., Behringer, D., and Nadiga, S.: An assessment of oceanic variability in the NCEP climate forecast system reanalysis, Clim. Dynam., 37, 2511-2539, doi:10.1007/s00382-010-0954-4, 2011. 